\title{
Monetary Policy, Bank Lending and Corporate Investment
}

\author{
Chaiporn Vithessonthi* \\ Sunway University Business School, Sunway University \\ No. 5, Jalan Universiti, Bandar Sunway, 47500 Selangoor Darul Ehsan, Malaysia \\ Tel: +60 374918622 Ext 7104; Fax: +60 356358633 \\ Email: chaipornv@ sunway.edu.my \\ Markus Schwaninger \\ Institute of Management, University of St. Gallen \\ Dufourstrasse 40a, CH-9000 St. Gallen, Switzerland \\ Tel: +41 71224 2382; Fax: +41 712242355 \\ Email: markus.schwaninger@unisg.ch \\ Matthias O. Müller \\ Greenwood Strategic Advisors AG \\ Zugerstrasse 40, CH-6314 Unterägeri, ZG, Switzerland \\ Tel: +41 4175474 47; Fax: +41 417547448 \\ Email: matthias.mueller@greenwood-ag.com
}

This version: 10 January 2017

* Corresponding author 


\title{
Monetary Policy, Bank Lending and Corporate Investment
}

\begin{abstract}
The purpose of this study is to shed light on the chain of causality from macroeconomic financial policy to the microeconomic investment function. Concretely, we aim to provide an in-depth analysis of the relationships between the monetary policy of central banks, the loan policy of commercial banks, and the investment behavior of firms. We focus on countries that conduct their monetary policy under the inflation-targeting framework. Our empirical analysis with data from Germany, Switzerland and Thailand provides several new insights. First, after controlling for the US monetary policy, the monetary policy in Germany and Thailand appears to influence the banks' lending rate in the short run (i.e. within two months), whereas the monetary policy in Switzerland seems to be ineffective at influencing the banks' lending rate in the short run. Second, our results show that the banks' lending rate has a negative effect on their loans and that this negative effect is weakened by their growth opportunities. Third, we find that the supply of bank loans plays a more pivotal role in determining firms' investment than the lending rate. Last but not least, we document that neither the lending rate nor the loan-to-assets ratio moderates the sensitivity of the firms' investment to growth opportunities.
\end{abstract}

JEL classification: E4; E5; G1; G2; G3

Keywords: Bank loans; corporate investment; inflation targeting; interest rate; monetary policy 


\section{Introduction}

In this paper, we attempt to complement prior studies that examine the effect of monetary policy on the economy (e.g., macroeconomic variables such as consumption, employment and investment). While this question has been debated amongst scholars (e.g., Bernanke and Blinder, 1992; Eisner, 1975; Hamburger, 1967; Milton, 1968, 1982) for several decades, the main conclusion remains evasive. On the one hand, several economists, such as Tucker (1966) note that even if monetary policy may be able to lower interest rates $^{1}$, it is unlikely to have a significant effect on price levels, investment and consumption in a timely manner. On the other hand, some scholars, such as Bernanke and Blinder (1992), Thorbecke and Alami (1992), Yu (1997), suggest that monetary policy has a significant effect on the economy.

The main research question in this paper is whether a central bank's monetary policy (which is measured as "monetary policy interest rate") influences corporate investment ${ }^{2}$ in countries that conduct their monetary policy under the inflation-targeting regime that has become popular over the past decades. To answer this question, we examine whether the

\footnotetext{
${ }^{1}$ Several scholars such as Kuttner (2001) and Cochrane and Piazzesi (2002) find that interest rates react to monetary policy.

${ }^{2}$ Theoretically, the effectiveness of monetary policy on the economy through the banking or credit channel transmission depends on (1) the responsiveness of market interest rate, especially banks lending rate, and loan supply to a change in monetary policy (Kashyap et al., 1993; Zwick, 1971) and (2) the responsiveness of firms' investment to market interest rate (Bernanke, 1993; Hardouvelis, 1987; Tanner, 1969; Tucker, 1966).
} 
monetary policy interest rate (hereafter "policy interest rate") affects the lending rate of banks, and if in turn it encourages or discourages firms' investment. Our results will shed light on the effectiveness of monetary policy in manipulating firms' investment in a more recent time. The insights from our study should be of interest to researchers in the field of finance, but also for anyone involved in financial policy-making.

Bernanke (1993) suggests that empirical evidence on the quantitative significance of the money and credit channels is limited, and that there is little evidence to suggest that in the US context, the Federal Reserve can influence the long-term real interest rates, or that investment significantly responds to changes in the real interest rates. Most recent studies on these issues are generally theoretical (e.g., Disyatat, 2011; Fich and Shivdasani, 2006), use the macro level data (e.g., Kashyap et al., 1993; Musso et al., 2011), and/or mainly examine the response of bank loans to changes in monetary policy using the bank level data (e.g., Dasgupta and Sengupta, 2007; Kishan and Opiela, 2012; Zhou et al., 2007). More importantly, the literature that examines the influence of monetary policy on bank behaviors (e.g., banks' lending rates and loan supply) and the effect of resulting changes in bank behaviors on corporate investment is very limited.

Therefore, in this paper, we try to fill a gap in the literature by providing empirical evidence on the influence of monetary policy on bank lending interest rates (hereafter "lending rate") and on the response of corporate investment to changes in the lending rate at the firm level, for countries that conduct a monetary policy under an inflation-targeting regime $^{3}$.

\footnotetext{
${ }^{3}$ See, e.g. Bernanke and Mihov (1997), Svensson (1999), Fourçans and Vranceanu (2004) and Golinelli and Rovelli (2005) for a detailed discussion on inflation targeting. Generally speaking, inflation targeting refers to a monetary policy framework in which a central bank
} 
While research on the effect of monetary policy on investment has been growing, empirical studies on this relation under the inflation-targeting regime, especially at the firm level and in developing countries, remain scare. Accordingly, our paper contributes to the monetary policy and corporate finance literature by empirically investigating (1) the effect of the policy interest rate on banks' lending rate and loan supply and (2) the effect of banks' lending rate and loan supply on corporate investment. We are using a firm-level analysis in three countries: Germany, Switzerland, and Thailand. Compared to the US, all of these three countries can be classified as bank-based economies. ${ }^{4}$ Using a sample of 22,000 firms in the Euro area and the UK, De Haan and Sterken (2006) find that a tightening monetary policy has a stronger effect on bank-dependent firms than on firms that are less dependent on banks for external finance. In view of this empirical evidence, it is reasonable to argue that the effectiveness of monetary policy on the economy through the credit channel transmission should be more evident in a bank-based country than in a capital-market-based country. Consequently, the focus on bank-based economies in our study allows for better identifying the effect of monetary policy on corporate investment through the credit channel mechanism because relative to firms in capital-market-based economics, firms in bank-based economies are less likely to substitute bonds for bank loans to satisfy external financing needs. In

sets a target level of inflation, and subsequently conducts its monetary policy to achieve this target.

${ }^{4}$ Firms that operate in a bank-based country tend to rely more on bank loans to meet external financing needs than firms operating in capital-market-based countries (e.g., the US). For a detailed discussion about the bank-based system in Germany, please see, for example, Vitols (2005). For a detailed comparison between the bank-based and market-based financial systems, please see Levine (2002). 
addition, all of these countries generally adopt the inflation-targeting regime, allowing for the examination of the effectiveness of conducting monetary policy under the inflation-targeting regime in developed and developing countries.

Given the reasons discussed above (e.g., that there is a lack of comprehensive studies about the influence of monetary policy on the banking sector and firm-level investment), our study covers three countries and spans the period from 1990 to 2013. In terms of empirical strategy, we use two different but complementary approaches: (1) panel OLS regressions and (2) panel quantile regressions. Several key findings emerge in our study. First, we show that a change in the policy interest rate generally has a short-term effect on the lending rate in two of the three countries under study. That is, we find that the change in the policy interest rate is positively related with the lending rate in Germany and Thailand. Second, our results consistently show that the lending rate has a negative impact on bank loans. Third, corporate investment responds negatively to a hike in the lending rate. Fourth, the supply of bank loans has a positive effect on the capital expenditure ratio. Fifth, the effect of the lending rate on investment is negative for financially unconstrained firms and is not significant for financially constrained firms. Sixth, the supply of bank loans is positively associated with corporate investment for both financially constrained and financially unconstrained firms. Last but not least, the positive effect of the supply of bank loans on corporate investment is evident for well-performing firms (e.g., firms with positive sales growth rates and/or positive return on assets $(R O A))$ but is not evident for poor performing firms (e.g., firms with zero or negative sales growth rates and/or zero or negative $R O A$ ).

Our findings complement not only the monetary policy literature that examines the impact of monetary policy on investment (e.g., Bernanke, 1993; Hardouvelis, 1987; Tanner, 1969; Tucker, 1966) but also the corporate finance literature that examines investment 
behaviors of firms (e.g., Boyle and Guthrie, 2003; Lyandres, 2007; Moyen, 2004; Moyen and Platikanov, 2013).

After this introduction we present a brief review of the literature related to our topic, and, based on the literature review, we develop our hypotheses in Section 2. We discuss our sample and data sources in Section 3. Then our research framework and empirical results are presented in Section 4. We reflect on the implications of our study and conclude the paper in Section 5 .

\section{Brief overview of related literature and hypothesis development}

In this section we briefly discuss prior theoretical and empirical studies that have examined the influence of changes in monetary policy on investment, especially the effect of changes in monetary policy on bank lending rates, and the effect of bank lending rates on investment. In addition, we complement the economics literature with the corporate finance literature by discussing firm-specific factors that have been found to affect corporate investment.

Traditionally, it has been argued that monetary policy exerts an influence on investment through two transmission mechanisms: the money (also known as "interest rate") and credit (also known as "bank lending") channels (see Bernanke and Blinder, 1988). That is, a change in monetary policy affects market interest rates and the amount of loans available to firms. For example, when the central bank attempts to slow the economy, it would conduct policies that reduce reserves from the banking system, which would in turn reduce the size of bank assets and liabilities. In doing so, the central bank attempts to reduce firms' investment due to (1) a higher cost of capital and/or (2) a reduced amount of external finance available to firms. Two important questions arise at this point: First, to what extent does a change in 
monetary policy affect the market interest rate? Second, what is the speed at which the market interest rate reacts to a change in monetary policy? These two questions are intertwined with respect to the effectiveness of the monetary policy on manipulating the real economy. Regarding the first question, it may happen that a tightening monetary policy has a significant effect on market interest rates, but mainly over long time horizons (e.g., say, with a lag of one year or longer), due to market frictions. Then, in terms of the second question, it is probably reasonable to conclude that a change in monetary policy affects the market interest rate. But, say, with a lag of one year, changes in monetary policy stance may appear to be less effective at altering a market interest rate in the short run.

Through the credit channel, changes in monetary policy affect the amount of bank loans available to firms (see e.g., Bernanke and Blinder, 1988; De Haan and Sterken, 2006; Disyatat, 2011). Due to information asymmetries between banks and firms and the weakening balance sheets of firms (e.g., reducing the ability of firms to service their current and future debt obligations), a tightening monetary policy causes banks to rebalance their portfolio of loans and cut back on makings loans to firms. Subsequently, a fall in bank loans has a negative effect on bank-dependent firms' investment. Several empirical studies provide mixed support for the credit channel. For instance, using a set of macro level data, Kashyap et al. (1993) find that a change in monetary policy has a significant effect on firms' composition of external finance. More specifically, they report that in response to tightening monetary policy stances, the amount of commercial papers increases and the amount of bank loans decreases, and that the fall in loan supply appears to influence investment, after controlling for interest rates. On the other hand, using bank-level data, Brissimis and Delis (2009) examine the evidence of the credit channel in six OECD countries (France, Germany, Greece, Japan, UK, and USA) during 1996-2003 and find that the credit channel appears to exist only in Greece and Japan. 
As discussed above, the two main transmission mechanisms of monetary policy are the money and credit channels. Through the money channel, changes in monetary policy affect market interest rates, i.e., the cost of funds to firms (see e.g., Bernanke and Blinder, 1992; Kuttner, 2001; Zwick, 1971). All else being equal, a higher cost of a firm's (financial) capital (i.e. the hurdle rate) for projects is likely to reduce its investment in a single-period model. However, scholars who examine the effect of monetary policy on investment in a multi-period setting argue that a lower interest rate may not necessarily induce firms' investments in the first period, i.e., that it is even possible that the cut in the interest rate may lower the firms' investments in the first period. For instance, Dasgupta and Sengupta (2007) argue that as a firm's liquidity balance increases (and correspondingly, the level of financial constraints for the firm decreases), it may reduce its investment today in response to an interest rate cut. One of explanations for this assumption is that when a firm has a high level of liquidity, its incentive to invest today may be relatively low, given that (1) the risk for the firm to not be able to invest in the future decreases, (2) an expected lower interest rate in the future increases the level of attractiveness of future projects, and (3) the firm becomes more conservative in selecting projects today. In particular, Dasgupta and Sengupta (2007) conjecture that a positive relation between interest rate and investment in the first period is more prominent than in the later periods, if monetary policy causes a parallel downward shift in the yield curve (in both the short-term interest rate and the long-term interest rate). These authors further argue that for an expansionary monetary policy to have a desired effect (i.e. stimulating investment today), the fall in the short-term interest rates must be substantially larger than the fall in the long-term interest rates.

In view of these arguments, we propose the following hypotheses, which we will test empirically: 
Hypothesis 1: A change in monetary policy is positively associated with a change in market interest rate in the short run. More specifically, a change in policy interest rate is positively associated with a change in banks' lending rate, at short horizons (i.e. within four quarters).

Hypothesis 2: The sensitivity of banks' loans to their growth opportunities decreases with the size of the lending rate. More specifically, during periods of high lending rates, the magnitude of the effect of a bank's growth opportunities on bank loans is smaller.

Hypothesis 3: The sensitivity of firms' investment to their investment opportunities decreases with the size of the lending rate. More specifically, a high lending rate weakens the effect of firms' investment sensitivity to their investment opportunities.

Hypothesis 4: The sensitivity of firms' investment to investment opportunities increases with the volume of bank loans offered. More specifically, a greater level of the supply of bank loans strengthens firms' investment sensitivity to investment opportunities.

What is new about these hypotheses? All of them have been discussed in the literature individually. Our new contribution rests on more than the individual hypotheses. We empirically study the detailed mechanisms of the effects of monetary policy on corporate investment in one single study. The main thrust should be an understanding of the causal chain from the decision of a central bank through the banks' lending rate and supply of loans to firms' investment.

\section{Data and variables}


For each country (i.e., Germany, Switzerland or Thailand), we collected data from Datastream of all banks that are listed on the stock exchanges in a country. Similar to Pais and Stork (2013), we select 1990 as the initial year because several banks' time-series are unavailable before that date. Our study period spans the period from 1990 to 2013 and consists of 12 banks in Germany, 22 in Switzerland, and 10 in Thailand, respectively, in the original sample. We first excluded banks that were not listed by the end of December 2010 . After excluding banks with missing key variables (see Table 1), our final bank sample consists of 25 banks in three countries.

Cross-country studies are typically complex due to differences in country-specific features. We try to use identical measures of the variables, whenever that is possible. We retrieve daily, monthly, and/or yearly macro-level time-series data from Datastream for Germany, Switzerland, and Thailand over the period spanning from January 1, 1990 to 31 December 2013. Ideally we would wish to use the specific lending rate for each bank; however, these data are not available. Therefore, we estimate the implied lending interest rate (INTRATE) for each bank by computing a ratio of total interest income to total loans. INTRATE indicates the average interest rate that a bank earns on its total loans over a period of one year. To reduce the effect of potentially spurious outliers, we winsorize (i.e., limit extreme values in the statistical data) all bank-level and firm-level variables at the $1 \%$ and 99\% levels. Please see Appendix A for the detailed description of variables used in this study.

To examine the effects of the lending rate and the supply of bank loans on corporate investment, we collect data from Datastream of all non-financial firms ${ }^{5}$ that are listed on the

\footnotetext{
${ }^{5}$ We exclude firms that are classfied as (1) banks, (2) financial services firms, (3) life insurane firms, and (4) non-life insurance firms. In addition, we exclude (1) equity instruments, (2) nonequity instruments, (3) real estate investment trusts, and (4) those that are
} 
stock exchanges in all three countries. As before, we exclude firms that were not listed before the end of December 2010. Our sample of non-financial firms consists of 13,283 firm-year observations. We winsorize all firm-level variables at the $1 \%$ and $99 \%$ levels.

Panel A of Table 1 reports the descriptive statistics for bank-level variables. The mean equity-to-assets ratio (EQUITYTA) for our sample of banks is $6.6 \%$, which is lower than the mean value of $9.4 \%$ for US banks during the period 1976-2007, as reported by Loutskina (2011). In addition, banks in our sample have lower deposit-to-assets ratios (60\%) than those of banks in the Southeast Asian region (74\%), as reported by Vithessonthi (2014), and those of US banks (86\%), as reported by Loutskina (2011). Panel B of Table 1 presents descriptive statistics for firm-level variables. CAPEX has a mean value of $5.84 \%$, which is slightly lower than that of US firms. For example, Hovakimian (2011) documents that the average investment ratio of US firms over the period 1980-2008 is $8.3 \%$.

\section{[PLEASE INSERT TABLE 1 HERE]}

Table 2 reports correlation coefficients for bank-level variables. While correlation coefficients between explanatory variables are highly significant, they are generally below 0.45. As a result, the issue of multicollinearity problems is not serious. We find that the lending interest rate (INTRATE) is negatively associated with the loan to assets ratio (LOANTA), indicating that the amount of loans tends to fall as the lending rate increases.

Table 3 presents correlation coefficients for firm-level variables. As all correlation coefficients between explanatory variables are below 0.43 , a multicollinearity problem is not of concern. The sign of the correlation coefficients is generally consistent with expectations.

under an unclassficied category from the sample. 
For example, while the capital expenditure ratio $(C A P E X)$ is positively correlated with firm size (LNTA), leverage ( $L E V)$, profitability $(R O A)$, fixed assets (FATA), dividends (DIVTA), investment opportunities $(M B V)$, and stock price performance $\left(S \_R E T U R N\right)$, it is negatively correlated with cash holdings (CASHTA), current ratios (CACL), operating risk (RISK_ROA), and inventories (INVTURN).

[PLEASE INSERT TABLE 2 HERE]

[PLEASE INSERT TABLE 3 HERE]

\section{Research framework and empirical results}

\subsection{The effect of monetary policy on interest rates}

Following prior studies such as Brämer et al. (2013), to test Hypothesis 1 predicting that a change in policy interest rate is positively associated with a change in market interest rate, we regress the lending rate on measures of the policy interest rate and control variables.

$$
\begin{aligned}
\Delta \text { ENDING }_{c, t}= & a_{0}+a_{1} \Delta M P U S_{c, t}+a_{2} \Delta M P_{c, t}+a_{3} \Delta M P_{c, t-1}+a_{4} \Delta M P_{c, t-2} \\
& +a_{5} \Delta M P_{c, t-3}+a_{6} \Delta M P_{c, t-4}+a_{7} \Delta M P_{c, t-5}+\varepsilon_{i, t},
\end{aligned}
$$

where $\triangle L E N D I N G_{, c, t}$, denotes the first difference in the lending rate for banks in country $c$ at time $t, \triangle M P U S_{t}$ denotes the first difference in the US effective federate funds rate ${ }^{6}$ at time $t$,

\footnotetext{
${ }^{6}$ As a robustness check, we alternatively use the US federal funds target rate. The pattern of the results remains generally unchanged.
} 
$\Delta M P_{c, t}$ denotes the first difference in the policy interest rate for country $c$ at time $t$, and $\varepsilon_{i, t}$ is the error term. We use the country-level lending rate provided by International Financial Statistics for banks listed in the country. However, the lending rate time-series for Germany is discontinued in 2003; therefore, we use short-term interest rates for Germany, provided by OECD, as an alternative measure of the lending rate for German banks.

A combination of a positive and significant effect of $\Delta M P_{c, t}, \Delta M P_{c, t-1}, \Delta M P_{c, t-2}$, $\Delta M P_{c, t-3}, \Delta M P_{c, t-4}$, and/or $\Delta M P_{c, t-5}$ in Equation (1) would indicate that the policy interest rate is associated with the lending rate. We use Euro Marginal Lending rate from European Central Bank (hereafter "MPDE") as a proxy for the policy interest rate in Germany (and the euro zone $)^{7}$, the Swiss target 3-month LIBOR rate (hereafter "MPSW") as a proxy for the policy interest rate in Switzerland, and the Bank of Thailand's one-day bilateral repurchase rate (hereafter "MPTH") as a proxy for the policy interest rate in Thailand. We use the 12month Frankfurt money market rate (BDMNY1Y), Switzerland mortgage rate (SWFNMRT), Thailand lending rate (THBTPLT) as rough proxies for the lending rates in Germany, Switzerland, and Thailand, respectively.

\subsubsection{Empirical results: The effects of monetary policy on bank lending rates}

The primary purpose of this section is to explore the relationship between the monetary policy interest rate (hereafter "policy interest rate") and the marketing interest rate,

\footnotetext{
${ }^{7}$ Fort he period prior to January 1, 1999, we use Lombard Rate as a proxy for the monetary policy interest rate for Germany. That is, we combine the two interest rate time series (of the Lombard Rate and the Euro Marginal Lending Rate) to create the monetary policy interest rate for the period 1990-2013 for Germany.
} 
which is approximated by the bank lending interest rate (hereafter "lending rate"). In examining the effect of the policy interest rate on the lending rate, we first recognize that the policy interest rate does not change on a daily basis, but usually only after a meeting of the monetary policy committee (e.g., the Federal Open Market Committee (FOMC) in the US). Following this reasoning, we estimate time-series regressions of Equation (1) for each country for the full sample period using the interest rates at a monthly frequency. ${ }^{8}$

Table 4 reports the results of OLS (Ordinary Least Squares) and GLM (Generalized Linear Model) regressions with the change in the lending rate as the dependent variable for each country in the sample ${ }^{9}$. In all specifications, we include the change in the US policy interest rate as a control variable, and the change in the corresponding country's policy interest rate and its five lags as the explanatory variables. ${ }^{10}$ In columns $1-3$ we estimate OLS

\footnotetext{
${ }^{8}$ We retrieve the required interest rates at daily freqencies and use the last observation of the month to convert the daily frequency data set to a monthly frequency data set.
}

${ }^{9}$ Our data set covers the period 1990.M7-2012.M5 for Germany, the period 2000.M72013.M12 for Switzerland, and the period 1994.M7-2013.M12 for Thailand.

${ }^{10}$ To address concerns that the monetary policy rate might be endogenous, we perform three additional tests. First, we undertake the Granger causality tests (with five lags of the first difference in the monthly monetary policy rate) to see whether the US monetary policy does Granger cause the monetary policy rate in Germany, Switzerland, and Thailand. We report the results of the Granger causality tests in Appendix C. Overall, the results suggest that we cannot reject the null hypothesis that the US monetary policy does not Granger cause the monetary policy rate in Germany and Thailand. We fail to reject the null hypothesis that the US monetary policy rate does Granger cause the monetary policy rate in Switzerland. Second, we estimate the OLS regression where the explanatory variables are the three lagged values 
regressions of Equation (1) with HAC (Heteroskedasticity-autocorrelation) robust standard errors, which are reported in the parentheses. In columns 4-6 we estimate GLM regressions of Equation (1) with Huber/White robust standard errors, which are reported in the parentheses.

Looking at the results across columns 1-6, we find that there is no contemporaneous positive relationship between the US monetary policy interest rate and the policy interest rate in Germany. After controlling for the influence of the US policy interest rate, the local policy interest rate is positively associated with the lending rate for Germany and Thailand. The results show that the lending rate in Switzerland does not contemporaneously react to the Swiss policy interest rate as well as its lags. Overall, we find that the current value of $\triangle M P$ (the first difference in the policy interest rate) is not affected by its past values or by the change in the US monetary policy rates. In a closely related study, Brämer et al. (2013) also document that over the period 2003-2009 the European Central Bank's policy interest rate is positively associated with the lending rate in Germany, which is similar to our findings. In addition, these authors note that compared to other EMU countries under study, France and Germany exhibit lower responses of the lending rate to the policy interest rate.

of the dependent variable (i.e. the first difference in the monthly monetary policy rate) for Germany, Switzerland, and Thailand. To conserve space, we do not tabulate the results. We find that the past values of the monetary policy rate generally do not affect the current value of the monetary policy for all three countries. Third, we estimate the Vector Autoregressions (VAR) models that include $\triangle \mathrm{MP}$ of Germany, Switzerland, Thailand, and the US (with three lags). The results show that $\Delta \mathrm{MP}$ for Germany, Switzerland, and Thailand is not affected by its lagged values, and that, consistent with the results of the Granger causality tests, $\triangle \mathrm{MP}$ of Switzerland is affected by the first lag of $\triangle \mathrm{MP}$ of the US. 
To test the robustness of our findings, we use the Vector Autoregressions (VAR) approach of prior studies (see e.g., Neuenkirch, 2013) by estimating the following VAR model for each country.

$$
\Delta y_{c, t}=\sum_{t=1}^{k} \alpha \Delta y_{c, t-i}+\mu_{t}
$$

where $y_{c, t}$ is a $3 \times 1$ vector of endogenous variables containing $\triangle \operatorname{LENDING}_{c, t}, \Delta M P U S_{c, t}$, and $\Delta M P_{c, t}$. For comparison purposes, we use four lags. We also use Akaike information criterion, Schwarz information criterion, and Hannan-Quinn information criterion to determine the number of lags. The Hannan-Quinn information criterion indicates that two to four lags are appropriate. To conserve space, we do not tabulate the results (which are available upon request). We find that consistent with the regression results, the monetary policy affects banks' lending rate in Germany and Thailand in the short-run (i.e., within two months).

Overall, empirical evidence reported in this section suggests that after controlling for the US monetary policy, the monetary policy in Germany and Thailand appears to influence banks' lending rate in the short-run (i.e. within two months), whereas the monetary policy in Switzerland seems to be ineffective at influencing banks' lending rate in the short-run. These results suggest that countries where important international financial markets are located (i.e. Switzerland in our study) are more likely to experience monetary policy to be ineffective as a means to affect short-run domestic market interest rates. The reason is that the domestic market interest rates are more aligned with the world's interest rate due to high degrees of capital mobility. Hence, Hypothesis 1 is confirmed for two countries and refuted for one. 


\subsection{The effect of interest rates on bank loans}

In this section, we address the question of whether the lending rate affects the supply of bank loans. As discussed in the literature, measuring the demand and supply of credits and bank loans is problematic as they are generally unobservable. We therefore use the value of outstanding bank loans as a rough proxy for the supply of bank loans. ${ }^{11}$

To test Hypothesis 2 predicting that the sensitivity of banks' loans to their growth opportunities decreases with the magnitude of the lending rate, we could use a two-step approach. In the first step, we regress banks' total loans normalized by total assets (LOANTA) on the banks' market-to-book ratio $(M B V)$, as a measure of growth opportunities, and control variables in a cross-sectional regression as follows:

$$
\operatorname{LOANTA}_{i, c, t}=\alpha+\beta_{1} M B V_{i, c, t-1}+\delta \text { BCONTROL }_{i, c, t-1}+\gamma \text { CCONTROL }_{c, t-1}+\varepsilon_{i, c, t},
$$

where BCONTROL is a vector of bank-level control variables for bank $i$ in country $c$ at time $t$-1, whereas CCONTROL is a vector of country-level control variables at time $t$ - 1 . We estimate Equation (3) for each year and have time series of yearly coefficients.

${ }^{11}$ The supply of bank loans can equivalently be viewed as the total value of loans that a bank can have on its books at a particular point in time if its balance sheet conforms with rules and regulations. The outstanding value of bank loans is the actual value of loans that the bank has at that time. Assume that the bank cannot actually have more oustanding loans than the maximum amount of loans (i.e. the supply of bank loans). Then, the oustanding value of bank loans at any point in time should be less than or equal to the supply of bank loans. 
To examine whether the lending rate affects bank loan sensitivity to $M B V$, in the second step, we regress the annual coefficient $\beta_{1}$ on the lending rate:

$$
\beta_{1, t}=\alpha+\beta_{2} L E N D I N G_{i, c, t-1}+\varepsilon_{i, c, t}
$$

where variables are defined as before. The estimated coefficient $\beta_{2}$ in Equation (3) indicates the marginal effect of the lending rate on the $M B V$ coefficient, and suggests whether the lending rate affects the cross-section of bank loan. It is important to note that if there is a persistent bank-level effect in the data (i.e. bank loans and $M B V$ are persistent), then we may obtain the standard errors of the coefficients in Equation (3) being inconsistent (e.g., biased downward). Panel OLS regressions are capable of addressing this issue by making panel OLS regressions unbiased. ${ }^{12}$ Therefore, we substitute Equation (4) into (3) and include firm-fixed effects and period-fixed effects as follows:

$$
\begin{aligned}
\text { LOANTA }_{i, c, t}= & \alpha+\beta_{3} M B V_{i, c, t-1}+\delta \text { BCONTROL }_{i, c, t-1}+\gamma \text { CCONTROL }_{c, t-1} \\
& +\beta_{4} M B V_{i, c, t-1} \text { LENDING }_{c, t-1}+\delta \text { BCONTROL }_{i, c, t-1} \text { LENDING }_{c, t-1} \\
& +\gamma \text { CCONTROL }_{c, t-1} \text { LENDING }_{c, t-1}+u_{i}+v_{t}+\varepsilon_{i, c, t},
\end{aligned}
$$

where $u_{i}$ and $v_{t}$ are firm-fixed effects and year-fixed effects, respectively. The coefficient $\beta_{4}$ on the interaction term in Equation (5) estimates the marginal impact of the lending rate on the $M B V$ coefficient in the same way as the coefficient $\beta_{2}$ in Equation (4) does.

\footnotetext{
12 The panel OLS model with fixed effects has been used in a number of recent studies such as Kishan and Opiela (2012) and McLean and Zhao (2014).
} 
We include, CCONTROL $\mathbf{C}_{\mathrm{c}, \mathrm{t}}$, which is a set of country-level variables $(\triangle G D P$, LNBSD, MKTRETURN, and TRADE) for country $c$ at time $t$ that may affect bank loans. The GDP growth rate $(\triangle G D P)$ is measured as the first difference in the natural logarithm of real GDP. A positive GDP growth rate should further encourage banks to lend more. Hence, the coefficient of $\triangle G D P$ should be positive. The natural logarithm of banking sector development $(L N B S D)$, which is the ratio of domestic credit to private sector by banks to GDP, is used to control for the influence of the banking system as the main source of credit. Stock market return (MKTRETURN), which is computed as the first difference in the natural logarithm of the stock market index, is a measure of stock market conditions and indicates the investors' sentiments about the economy. A positive MKTRETURN value is likely to encourage banks to provide more loans; hence, we expect the coefficient of MKTRETURN to be positive. International trade (TRADE), which is computed as the percentage share of the sum of imports and exports to GDP, is a proxy for the international trade performance of a country.

We estimate a series of unbalanced panel OLS regressions of Equation (4) using (a) firm-fixed effects and period-fixed effects, (b) country-fixed effects and period-fixed effects, and (c) without fixed effects. For all panel OLS regressions, standard errors are clustered at the bank level. They are robust to heteroskedasticity and serial correlations between the residuals. As we study banks in a cross-country setting, it is also important to control for unobservable time-invariant effects at the country level that may have a significant effect on behaviors of banks and the dependent variable. As a result, we include the country-fixed effects in some specifications to control for the omitted unobservable time-invariant countrylevel factors. 


\subsubsection{Empirical results: The effects of the lending rate on bank loans}

Table 5 presents the estimation results of unbalanced panel OLS regressions of the loan ratio (LOANTA), which is computed as total loans scaled by total assets, on the lending rate (INTRATE). The latter is computed as the ratio of total interest income to total loans (in $\%$ ) for each bank, for a final sample of 25 banks in Germany, Switzerland, and Thailand during 1990-2013. In column 1 of Table 5, we estimate the baseline regressions by regressing the loan ratio (LOANTA) on bank- and country-level control variables only (without firmfixed, country-fixed, and period-fixed effects), with the adjusted $R^{2}$ is $57.4 \%$. A high value of the adjusted $R^{2}$ suggests that the bank- and country-level control variables can explain substantial variation in the loan ratio. Our results show that when country- and year-fixed effects are included in the baseline regression (see column 2 ), the adjusted $R^{2}$ increases to $69.5 \%$, and that when firm- and year-fixed effects are included in the baseline regression (see column 3), the adjusted $R^{2}$ increases to $70.1 \%$. With country-fixed effects and period-fixed effects, two bank-level control variables-bank size (LNTA) and the deposit-to-asset ratio (DEPTA - - have effects on the loan ratio, as shown in columns 2, 3,6 and 8. With firm-fixed effects and period-fixed effects, two bank-level control variables-the equity ratio (EQUITYTA) and operating performance $(R O A)$ - are associated with bank loans (see columns 4, 5, 7 and 9). Evidence of the positive effect of the equity ratio on the lending rate is consistent with Carlson et al. (2013), who document a positive relationship between capital ratios and bank lending in the US.

In columns 2 and 4, we add INTRATE to the models and find that the coefficients on INTRATE are negative and highly significant, thereby indicating that the lending rate has a negative and significant effect on the loan ratio of banks. One plausible explanation for the negative effect is that the higher lending rate may reflect higher risk premium associated with 
a higher risk level of the average firm in the country. When the average borrower has substantially higher risk, banks' loan screening process may result in more rejected loan applications and thus a lower amount of loans granted to the borrowers. Another possible explanation is that firms may show a lower demand for loans because their projects become less profitable at a higher cost of debt. Both explanations are not mutually exclusive. Our results demonstrate the importance of using the bank-specific interest rate to examine the effect of the interest rate on the supply of bank loans. Otherwise one may get to less robust conclusions: in a closely relate study, Rondorf (2012), using the aggregate level data set, finds that the interest rate, which is measured as the yield on a 10-year government bond, has no effect on bank loans for a sample of countries in the European monetary union over the period 1999-2008. Overall, regardless of whether we include bank-fixed effects or countryfixed effects, the negative effect of the lending rate continues to hold in all specifications.

In columns 3 and 5, we include both INTRATE and INTERATE $\times M B V$ in the models. The coefficients on INTRATE remain negative and statistically significant, while the coefficients on the interaction term are statistically significant at the 5\% and $10 \%$ level. Given that the main effects of $M B V$ on the loan ratio are generally insignificant in most specifications, and the significant coefficients on the interaction term, the results suggest that the negative effect of the lending rate on bank loans is weakened by growth opportunities. As a result, Hypothesis 2, which predicts that the sensitivity of bank loans to a growth opportunity decreases with the lending rate, is not supported.

[PLEASE INSERT TABLE 5 HERE]

To understand conditions under which the negative effect of the lending rate on bank loans might be strengthened or weakened, we estimate a series of regressions in column 6-9. 
First, we test whether the effect of the lending rate on bank loans is asymmetric, depending on the stage of economic development. We add an interaction term between INTRATE and a development $(D E V)$ dummy variable, which takes a value of one for developed countries and zero otherwise, in columns 6 and 7. The coefficients on the interaction term are not statistically significant, implying that the effect of the lending rate is not asymmetric with respect to the stage of economic development. Then, we add an interaction term between INTRATE and a global financial crisis $(G F C)$ dummy variable, which takes a value of one for observations between 2007 and 2013 and zero otherwise, in columns 8 and 9. The results show that the coefficients on the interaction term between INTRATE and GFC are positive and highly significant. Taken together, evidence suggests that the negative effect of the lending rate on bank loans is weaker during the global financial crisis period. This finding is in line with prior studies, as in Ivashina and Scharfstein (2010), that document an increase in commercial and industrial loans in the US during the global financial crisis of 2007-2009, which is largely driven by an increase in existing credit-line drawdowns by firms.

If banks choose to have a target level of loans and to vary the supply of loans depending on the level of the lending rate, then we should observe variation in the sensitivity of bank loans to the lending rate. We examine this possibility by using the quantiles of the distribution of bank loans. It is possible that the supply of bank loans reacts more strongly to the lending rate in the left tail or in the right tail than at the median. Therefore, we estimate panel quantile regressions. For brevity, we tabulate the estimation results for three different quantiles: 25th percentile (Q1), 50th percentile (median, Q2), and 75th percentile (Q3). We estimate all quantile regressions using Huber Sandwich standard errors and covariance. Table 6 presents our results of panel quantile regressions for the full sample.

In columns 1-3 of Table 6 we report the results of the main specifications including INTRATE and control variables. In columns 4-6 we add the interaction term between 
INTRATE and $M B V$ in the specifications. Evidence shows that the effect of the lending rate is negative and highly significant at the 50th percentile and that the sensitivity of bank loans to growth opportunities is not moderated by the lending rate.

\section{[PLEASE INSERT TABLE 6 HERE]}

\subsection{The effect of interest rates on corporate investment}

Applying the panel OLS regression approach used in the previous section, we test Hypotheses 3 and 4 in this section. Hypothesis 3 predicts that the sensitivity of a firm's investment to its investment opportunity decreases with the lending rate, while Hypothesis 4 predicts that the sensitivity of a firm's investment to its investment opportunity increases with the supply of bank loans.

To test Hypothesis 3, we estimate a series of panel OLS regressions of the following equation:

$$
\begin{aligned}
\text { CAPEX }_{i, c, t} & =\alpha+\beta_{1} \text { MBV }_{i, c, t-1}+\beta_{2} \text { LENDING }_{i, c, t-1}+\delta \mathbf{Z}_{i, c, t-1}+\gamma \text { CCONTROL }_{c, t-1} \\
& +\beta_{3} M B V_{i, c, t-1} \operatorname{LENDING}_{i, c, t-1}+\delta \mathbf{Z}_{i, c, t-1} \operatorname{LENDING}_{i, c, t-1}+u_{i}+v_{t}+\varepsilon_{i, c, t},
\end{aligned}
$$

where $C A P E X_{i, c, t}$ denotes the capital expenditure ratio for firm $i$ in country $c$ at time $t$, which

is measured as the ratio of capital expenditure to prior-period assets; CCONTROL is a vector of country-specific control variables. A negative coefficient of $\operatorname{LENDING}_{t-1}$ will provide empirical support for Hypothesis 3 predicting that the interest rate weakens the effect of investment opportunities on corporate investment. 
To test Hypothesis 4 predicting that bank loans affect the sensitivity of investment to a growth opportunity, we estimate the following panel OLS regression:

$$
\begin{aligned}
\text { CAPEX }_{i, c, t}= & \alpha+\beta_{1} M B V_{i, c, t-1}+\beta_{2} \operatorname{ALOANTA}_{c, t-1}+\delta \mathbf{Z}_{i, c, t-1}+\gamma \text { CCONTROL }_{c, t-1} \\
& +\beta_{3} M B V_{i, c, t-1} A L O A N T A_{c, t-1}+\gamma \mathbf{Z}_{i, c, t-1} A L O A N T A_{c, t-1}+u_{i}+v_{t}+\varepsilon_{i, c, t}
\end{aligned}
$$

where $A L O A N T A_{t,}$ is the average ratio of total loans to total assets for country $c$ at time $t$., and $\mathbf{Z}$ is a vector of firm-specific characteristics for firm $i$ in country $c$ at time $t$ that have been found to affect corporate investment as our firm-level control variables. As in the previous section, we also include, CCONTROL $_{c, t}$, which is a set of country-level variables $(\triangle G D P$ and MKTRETURN, and TRADE) for country $c$ at time $t$ that may affect corporate investment. For all panel OLS regressions, standard errors are clustered at the firm level. They are robust to heteroskedasticity and serial correlations between the residuals. A positive coefficient of the interaction term between $M B V_{i, c, t-1} A L O A N T A_{t-1}$ will provide empirical support for Hypothesis 4 predicting that bank loans affect the sensitivity of investment to a growth opportunity.

$\mathbf{Z}$ includes 11 firm-level control variables: size, leverage, cash-to-asset ratio, current ratio, operating performance $(R O A)$, operating risk, fixed-assets ratio, dividend-to-assets ratio, market-to-book ratio, stock returns, and inventory turnover ratio. Financial leverage ( $L E V$ ) defined as the ratio of the book value of total debt to the book value of total assets, is included to control for the firm's financial risk and capital structure. To control for a firm's liquidity, we use three variables. Cash-to-assets ratio (CASHTA) is the ratio of cash to total assets. Current ratio $(C A C L)$ defined as the ratio of current asset to current liabilities, is used as a proxy for a firm's liquidity. Dividend-to-assets ratio is computed as the ratio of cash dividend to assets. Firms with better operating performance are more likely to further expand 
their operations; therefore, we include three proxies for operating performance Our first measure is the return on assets ratio $(R O A)$, which is computed as the ratio of EBIT to total assets. The second measure is gross profit margin $(G P M)$, which is the ratio of gross profit to net revenues. Our third measure of operating performance is the inventory turnover ratio (INVTURN), which is measured as the ratio of inventories to the cost of goods sold. A high value of the inventory turnover ratio suggests that a firm carries a large amount of inventories. To control for a firm's operating risk (RISK_ROA), we compute the three-year moving standard deviation of ROA for each firm. Fixed assets ratio (FATA) is computed as the non-current assets to total assets. To control for a firm's investment opportunities, we use two measures. First, the market-to-book ratio $(M B V)$ is measured as the ratio of the market value of equity to the book value of equity. Second, a firm's annual equity return $\left(S \_R E T U R N\right)$ is computed as the first difference in the natural logarithm of stock price at the end of the year. A full description of the variables is provided in Appendix A.

\subsubsection{Empirical results: The effect of interest rates and bank loans on corporate investment}

Table 7 provides the results for the unbalanced panel OLS regressions using the capital expenditure ratio $(C A P E X)$ as the dependent variable. In all regressions, robust standard errors are clustered at the firm level. We include country-fixed effects and yearfixed effects in all regressions. In column 1, the regression contains all control variables; in columns 2 and 3, we separately add the lending rate (LENDING) and the loan-to-assets ratio (ALOANTA); in column 4 we include both the lending rate and the loan-to-asset ratios in the

model; in column 5, we add the interaction term between $L E N D I N G$ and $M B V$; in column 6, we add the interaction term between ALOANTA and $M B V$. 


\section{[PLEASE INSERT TABLE 7 HERE]}

Generally, the signs of the coefficients on control variables are consistent with the literature. For country-level variables, the GDP growth rate $(\triangle G D P)$ has a positive effect on investment, as does the stock market return (MKTRETURN). Similar to prior studies, such as Lang et al. (1996) and Ahn et al. (2006), financial leverage ratio (LEV) is negatively associated with investment. As we use gross profit margin (GPM) to control for the product market competition, high values for $G P M$ indicates that the firm is operating in a product market with relatively low levels of competition. Our findings suggest that firms that have high $G P M$ tend to invest less. One possible explanation for this negative effect is that they operate in a relatively less competitive market; therefore, additional investments may not be required to stay competitive. ${ }^{13}$ The negative coefficient on $R I S K \_R O A$ implies that firms with higher degrees of operating risk are more inclined to invest less, which may be due to uncertainty in their businesses. Consistent with prior studies such as Lang et al. (1996),we find that firms with good performance (ROA), more cash (CASHTA), more fixed assets $(F A T A)$, good stock returns $\left(S \_R E T U R N\right)$, and good investment opportunities $(M B V)$ are more likely to make more capital expenditures. The contemporaneous and positive association between cash flows and investment has also been documented by McLean and Zhao (2014).

\footnotetext{
${ }^{13}$ Another explanation highlights that managers and potential investors are subject to shorttermism, which often leads to a neglect of the investment activity (Kędzior and Rozkrut, 2014). Finally, a preference for immediate gratification appears to be a wide-spread phenomenon (see e.g., Mischel et al., 1972; O'Donoghue and Rabin, 2000).
} 
The results in columns 2 and 3 show that the lending rate (LENDING) has a negative effect on investment, and that the loan ratio (ALOANTA) has a positive on investment. When we include both LENDING and ALOANTA together, the effect of LENDING is only statistically at the $10 \%$ level in all models. On the basis of these findings, it is reasonable to conclude that the supply of bank loans, rather than the lending rate, plays a more pivotal role in determining firms' investment. Our finding of the positive association between the supply of bank loans and corporate investment is consistent with Chava and Purnanandam (2011) who find that compared to firms that have access to the public-debt market, bank-dependent firms cut back investment more strongly following adverse shocks to the supply of bank loans in the US during the Russian financial crisis of 1998.

While firms with better investment opportunities tend to invest more as the coefficients on $M B V$ are positive and highly significant in all models, the findings in columns 5 and 6 indicate that neither the lending rate nor the loan-to-assets ratio moderates the sensitivity of investment to growth opportunities. Overall, our evidence in Table 7 provides no support to both Hypotheses 3 and 4.

\section{[PLEASE INSERT TABLE 8 HERE]}

To provide additional evidence on whether the lending rate and the supply of bank loans have differential effects on investment, depending on firm characteristics. Table 8 reports the results for our subsample analysis. First, we examine whether the effects of the lending late and the supply of bank loans on investment are moderated by financial constraints of firms. We add an interaction term between LENDING (ALOANTA) and a financial constraint $(F I N C)$ dummy variable, which take a value of one for a firm that does 
not pay dividends in the previous year and zero otherwise ${ }^{14}$, in column 1 (2) of Table 8 . The coefficients on the interaction term in columns 1 and 2 are negative and statistically significant, suggesting that the sensitivity of investment to the lending rate is stronger for financially constrained firms than for financially unconstrained firms, and that the sensitivity of investment to the supply of bank loans is weaker for financially constrained firms. In column 3, the coefficient on the interaction term between LENDING and FINC remains negative and highly significant when both interaction terms are included together.

We estimate the full specification for financially unconstrained firms (see column 4) and for financially constrained firms (see column 5). The positive effect of the supply of bank loan is evident for financially unconstrained and for financially constrained firms, whereas the negative effect of the lending rate is only evident for financially unconstrained firms. One plausible explanation for the differential effects is that for financially constrained firms, to make new investments, external financing is required and hence, the supply of bank loans becomes a key factor.

Intuitively, one would expect growing firms to expand further. As a result, the effects of the lending rate and the supply of bank loans may differ for growing firms. To test this assumption, we use a sales growth $(S G R O W)$ dummy variable that takes a value of one for firms that has a positive growth rate of net sales and zero otherwise. We split our sample based on whether observations have a positive value of SGROW at time $t-1$. We estimate our regressions for both samples in columns 6 and 7. The results show that for firms with positive sales growth rates, the supply of loans tend to weakly encourage them to spend more on

${ }^{14}$ Our approach is consistent with prior studies such as Hovakimian (2011), who classifies firms as financially constrained if they did not pay cash dividends in a particular period, and firms as financially unconstrained if they paid cash dividends. 
capital expenditure in the following year. For firms with zero or negative growth rate, neither the lending rate nor the supply of bank loans has an effect on investment.

We now test whether firms with good performance tend to invest more when the supply of loans increases or when the lending rate decreases. We create a good performance $(P E R F)$ dummy variable that takes a value of one for observations with a positive value of $R O A$ at time $t-1$ and zero otherwise. The basic idea here is that firms with poor performance are more likely to cut back on spending as a means to improve firm performance. Hence, the effects of bank loans and the lending rate should be non-existent for poorly performing firms and should be substantial for firms with good performance. We estimate the regressions for both subsamples in columns 8 and 9. As expected, the supply of bank loans has a positive effect on investment for good performing firms only. Neither the lending rate nor the supply of bank loans has an impact on investment for poor performing firms.

As a robustness check, we alternatively use the natural logarithm of the capital expenditure ratio $(L N C A P E X)$ as the dependent variable. We find that the results are generally similar to those reported in Tables 7 and 8. For illustration purpose, we provide some of the results in Appendix B.

\section{Implications and conclusions}

Using data from three countries (i.e., Germany, Switzerland, and Thailand) that conduct their monetary policy under the inflation-targeting regime, we study how banks react to the central bank's monetary policy changes and how firms react to changes in the interest rate. We develop and empirically test four hypotheses. Of the four hypotheses presented at the outset, only one is confirmed (Hypothesis 1) while three are refuted (Hypotheses 2 to 4 ). Our key findings can be summarized as follows. After controlling for the US monetary 
policy, the monetary policy in Germany and Thailand appears to influence the banks' lending rate in the short run (i.e. within two months), whereas the monetary policy in Switzerland seems to be ineffective at influencing the banks' lending rate in the short run. These findings suggest that for small, open and advanced economies such as Switzerland, central banks' monetary policy is not effective as a means to influence commercial banks' interest rate. One plausible explanation is that as one of the global financial centers, Switzerland is open to capital mobility that renders the monetary policy actions ineffective.

Our results show that the banks' lending rate has a negative effect on their loans and that this negative effect is weakened by their growth opportunities. We further find that the supply of bank loans, rather than the lending rate, plays a more pivotal role in determining firms' investment. Our findings also suggest that neither the lending rate nor the loan-toassets ratio moderates the sensitivity of investment to growth opportunities.

These findings have some ramifications for central banks, especially those conducting monetary policy under an inflation-targeting regime. Take our finding that the sensitivity of the firm's investment to investment opportunities is not affected by the lending rate: this suggests that central banks may have to reconsider the use of monetary policy as a means to encourage/discourage corporate investment. While central banks might be concerned that the positive relationship between the firm's investment opportunities and its investment could be strengthened by the supply of bank loans, our findings suggest that this is not the case. Overall, our results provide empirical evidence for channels through which changes in monetary policy could affect corporate investments. For instance, we find that the banks' lending rate has a negative effect on their loans and that the aggregate-level bank loan is positively associated with the firm-level capital investment. These findings suggest that to reduce the firm-level investment, the central bank in Germany, Switzerland, and/or Thailand 
should try to reduce the supply of bank loans since it plays a more important role in determining the firm-level investment than the lending rate.

\section{Appendix A}

Appendix A: Variable description and summary statistics

\begin{tabular}{|c|c|}
\hline Variable & Description \\
\hline $\begin{array}{l}\text { Panel A: Macro- } \\
\text { level variables }\end{array}$ & \\
\hline LENDING & The average lending rate of commercial banks (in percent) \\
\hline$M P$ & $\begin{array}{l}M P \text { denotes the monetary policy interest rate }(\%) \text {. Euro Main } \\
\text { Refinancing European Central Bank rate }(E U R O R E F) \text {, the Swiss } \\
\text { target 3-month LIBOR rate (SWSNBTI), and the Bank of Thailand's } \\
\text { one-day bilateral repurchase rate }(T H B R P 1 D) \text { are used as a proxy for } \\
\text { a monetary policy interest rate for Germany (and the euro zone), } \\
\text { Switzerland, and Thailand, respectively. }\end{array}$ \\
\hline MPUS & $\begin{array}{l}\text { MPUS refers to the monetary policy interest rate }(\%) \text { for the US, } \\
\text { which is measured as the effective federal funds rate. }\end{array}$ \\
\hline$\triangle M P$ & The first difference in $M P$. \\
\hline$\triangle M P U S$ & The first difference in MPUS. \\
\hline$\triangle G D P$ & The GDP growth rate $(\%)$. \\
\hline ALOANTA & $\begin{array}{l}\text { ALOANTA is the cross-section average loan-to-assets ratio (LOANTA) } \\
\text { of banks for each country. }\end{array}$ \\
\hline MKTRETURN & $\begin{array}{l}\text { Stock market return (in percent), measured as the first difference in } \\
\text { the natural logarithm of the stock market index. }\end{array}$ \\
\hline
\end{tabular}

Panel B: Bank- and Firm-level variables CAPEX

CASHTA

$C A C L$

Capital expenditure ratio, measured as the ratio of capital expenditure to prior-period assets for each firm.

Cash ratio, measured as the ratio of cash to total assets for each firm Current ratio is measured as the ratio of current assets to current liabilities for each firm

$D E V$

DIVTA

A development dummy variable takes a value of one for firm-year observations in developed countries and zero otherwise.

EQUITYTA Dividend-to-assets ratio is the ratio of cash dividends to total assets for each firm.

FATA Capitalization ratio is measured as the ratio of equity to total assets (in\%) for each bank.

Fixed-asset ratio denotes the ratio of non-current assets to total assets for each firm

INTRATE Implied lending interest rate (\%) is computed as the ratio of interest income to total loans of a bank

INVTURN Inventory turnover is the ratio of inventories to the cost of goods sold for each firm.

LEV Leverage (\%) is measured as the ratio of total debt to total assets for each firm. Loan loss reserve ratio, measure as the ratio of loan loss reserves to 
S_RETURN

LNTA

LOANTA

$M B V$

PERF

RISK_ROA

$R O A$

$\operatorname{ROS}$

SGROW

$T A$

REAL TA total assets (in \%)

Stock return (\%), measured as the first difference in the natural logarithm of the stock price for each bank/firm.

The natural log of real total assets $\left(R E A L_{-} T A\right)$ in millions USD for each bank/firm.

Loan to asset ratio \%) is measured as the ratio of total loans to total assets for each bank.

Market-to-book is measured as the ratio of the market value of equity to the book value of equity for each bank/firm.

A good performance dummy variable takes a value of one for a firm that has a positive value of $R O A$ at time $t-1$, and zero otherwise.

Operating risk is the three-year moving standard deviation of $R O A$.

Return on assets (\%) is measured as the ratio of EBIT to total assets for each bank/firm.

Return on sales (\%) is measured as the ratio of EBIT to sales for each bank/firm.

A sales growth dummy variable takes a value of one for a firm that has a positive growth rate of net sales at time $t$ - 1 , and zero otherwise.

Firm size is computed as total assets (in millions USD) scaled by the end of year exchange rate (domestic currency/USD) for each bank/firm.

The book value of real total assets is computed as the book value of total assets in millions USD deflated by US CPI (CPI =100 in 2010). 


\section{Appendix B}

Appendix B: Panel OLS regressions of the capital expenditure ratio

This table presents the panel OLS regressions of the natural logarithm of the capital expenditure ratio (LNCAPEX) on the lending rate (LENDING) and the loan-to-asset ratio (ALOANTA) for a final sample of publicly listed firms in Germany, Switzerland, and Thailand over the period 1990-2013. All right-hand variables are lagged one period. Heteroscedasticity-robust standard errors, which are clustered at the firm level, are reported in parentheses. Country-fixed and year-fixed effects are included in all regressions. Symbols ***, **, and * denote significance at the $1 \%, 5 \%$ and $10 \%$ levels, respectively.

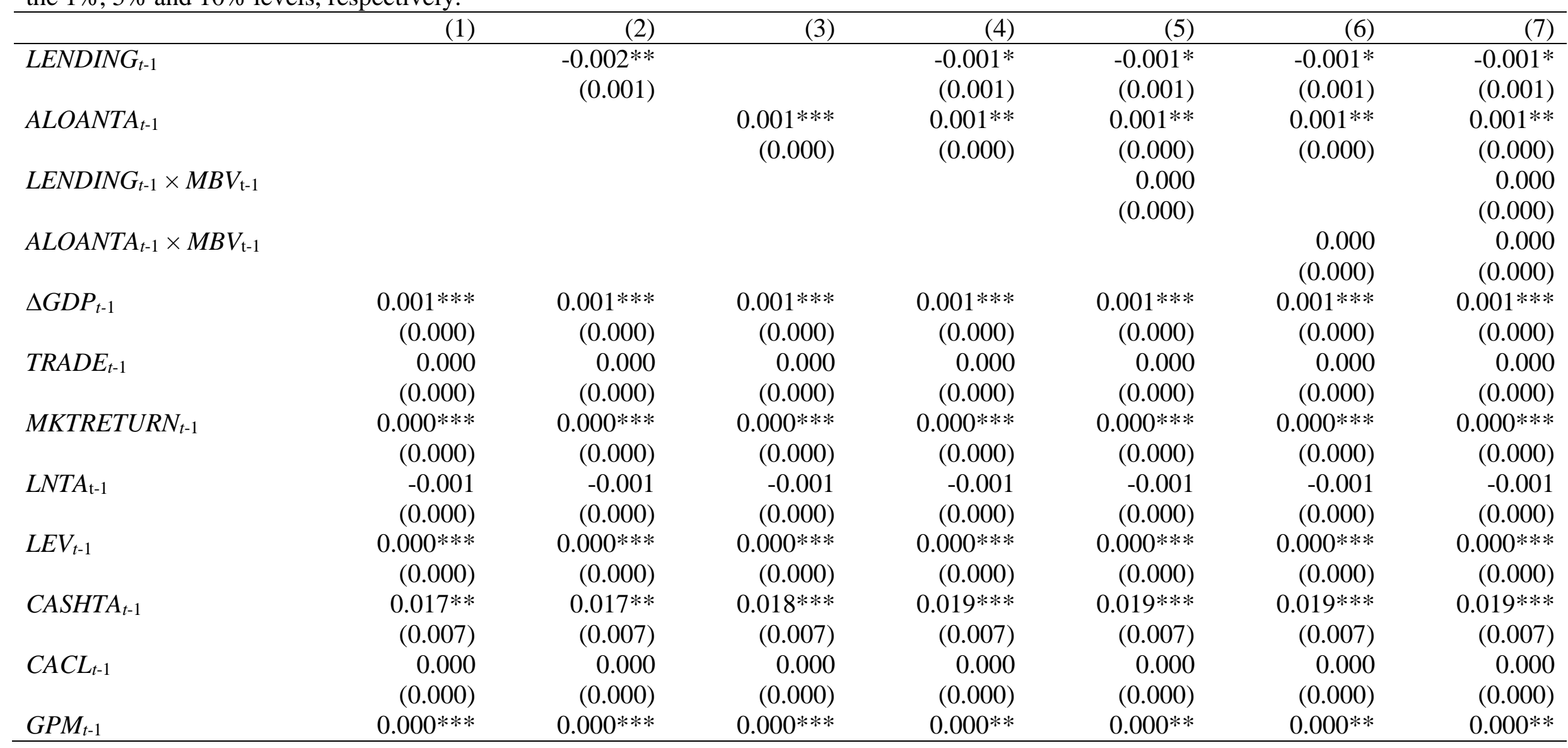




\begin{tabular}{|c|c|c|c|c|c|c|c|}
\hline & $(0.000)$ & $(0.000)$ & $(0.000)$ & $(0.000)$ & $(0.000)$ & $(0.000)$ & $(0.000)$ \\
\hline \multirow{2}{*}{$R O A_{t-1}$} & $0.000 * * *$ & $0.000 * * *$ & $0.000 * * *$ & $0.000 * * *$ & $0.000 * * *$ & $0.000 * * *$ & $0.000 * * *$ \\
\hline & $(0.000)$ & $(0.000)$ & $(0.000)$ & $(0.000)$ & $(0.000)$ & $(0.000)$ & $(0.000)$ \\
\hline \multirow[t]{2}{*}{$R I S K \_R O A_{t-1}$} & $0.000 * *$ & $0.000 * *$ & $0.000 * *$ & $0.000 * *$ & $0.000 * *$ & $0.000 * *$ & $0.000 * *$ \\
\hline & $(0.000)$ & $(0.000)$ & $(0.000)$ & $(0.000)$ & $(0.000)$ & $(0.000)$ & $(0.000)$ \\
\hline \multirow[t]{2}{*}{$F A T A_{t-1}$} & $0.058 * * *$ & $0.058 * * *$ & $0.059 * * *$ & $0.059 * * *$ & $0.059 * * *$ & $0.059 * * *$ & $0.059 * * *$ \\
\hline & $(0.005)$ & $(0.005)$ & $(0.005)$ & $(0.005)$ & $(0.005)$ & $(0.005)$ & $(0.005)$ \\
\hline \multirow[t]{2}{*}{$D I V T A_{t-1}$} & 0.003 & 0.003 & 0.003 & 0.003 & 0.003 & 0.003 & 0.003 \\
\hline & $(0.004)$ & $(0.004)$ & $(0.004)$ & $(0.004)$ & $(0.004)$ & $(0.004)$ & $(0.004)$ \\
\hline \multirow{2}{*}{$M B V_{\mathrm{t}-1}$} & $0.001 * * *$ & $0.001 * * *$ & $0.001 * * *$ & $0.001 * * *$ & $0.001 * * *$ & $0.001 * * *$ & $0.001 * * *$ \\
\hline & $(0.000)$ & $(0.000)$ & $(0.000)$ & $(0.000)$ & $(0.000)$ & $(0.000)$ & $(0.000)$ \\
\hline \multirow[t]{2}{*}{$S_{-} R E T U R N_{\mathrm{t}-1}$} & $0.000 * * *$ & $0.000 * * *$ & $0.000 * * *$ & $0.000 * * *$ & $0.000 * * *$ & $0.000 * * *$ & $0.000 * * *$ \\
\hline & $(0.000)$ & $(0.000)$ & $(0.000)$ & $(0.000)$ & $(0.000)$ & $(0.000)$ & $(0.000)$ \\
\hline \multirow[t]{2}{*}{$I N V T U R N_{\mathrm{t}-1}$} & $-0.005 * * *$ & $-0.004 * * *$ & $-0.004 * * *$ & $-0.004 * * *$ & $-0.004 * * *$ & $-0.004 * * *$ & $-0.004 * * *$ \\
\hline & $(0.001)$ & $(0.001)$ & $(0.001)$ & $(0.001)$ & $(0.001)$ & $(0.001)$ & $(0.001)$ \\
\hline \multirow[t]{2}{*}{ Constant } & $0.035^{*}$ & $0.075 * * *$ & -0.010 & 0.025 & 0.025 & 0.025 & 0.025 \\
\hline & $(0.018)$ & $(0.023)$ & $(0.025)$ & $(0.030)$ & $(0.030)$ & $(0.030)$ & $(0.030)$ \\
\hline Adjusted $R^{2}$ & 0.116 & 0.116 & 0.117 & 0.117 & 0.117 & 0.117 & 0.117 \\
\hline$F$-statistic & $44.361 * * *$ & $43.454 * * *$ & $43.699 * * *$ & $42.709 * * *$ & $41.638 * * *$ & $41.638 * * *$ & $40.621 * * *$ \\
\hline Firms included & 1,120 & 1,120 & 1,120 & 1,120 & 1,120 & 1,120 & 1,120 \\
\hline Observations & 12,239 & 12,239 & 12,239 & 12,239 & 12,239 & 12,239 & 12,239 \\
\hline
\end{tabular}




\section{Appendix C}

Appendix C: The Granger Causality Tests

This table presents the result of the Granger causality tests of the monetary policy rate with 5 lags. $\triangle M P$ denotes the first difference in the monthly policy interest rate for each country. DE, SW, TH, US denote Germany, Switzerland, Thailand, and US, respectively. Symbols $* * *, * *$, and $*$ denote significance at the $1 \%, 5 \%$ and $10 \%$ levels, respectively.

\begin{tabular}{lrrr}
\hline Null Hypothesis: & $\mathrm{N}$ & F-Statistic & P-value \\
\hline$\Delta M P_{S W}$ does not Granger Cause $\triangle M P_{D E}$ & 162 & 1.205 & 0.309 \\
$\Delta M P_{D E}$ does not Granger Cause $\triangle M P_{S W}$ & & 5.548 & 0.000 \\
$\Delta M P_{T H}$ does not Granger Cause $\triangle M P_{D E}$ & 234 & 0.402 & 0.847 \\
$\Delta M P_{D E}$ does not Granger Cause $\triangle M P_{T H}$ & & 0.475 & 0.794 \\
$\Delta M P_{U S}$ does not Granger Cause $\triangle M P_{D E}$ & 282 & 1.295 & 0.266 \\
$\Delta M P_{D E}$ does not Granger Cause $\triangle M P_{U S}$ & & 0.836 & 0.525 \\
$\Delta M P_{T H}$ does not Granger Cause $\triangle M P_{S W}$ & 162 & 0.718 & 0.611 \\
$\Delta M P_{S W}$ does not Granger Cause $\triangle M P_{T H}$ & & 7.249 & 0.000 \\
$\Delta M P_{U S}$ does not Granger Cause $\triangle M P_{S W}$ & 162 & 4.093 & 0.002 \\
$\Delta M P_{S W}$ does not Granger Cause $\triangle M P_{U S}$ & & 1.367 & 0.240 \\
$\Delta M P_{U S}$ does not Granger Cause $\triangle M P_{T H}$ & 234 & 1.935 & 0.090 \\
$\Delta M P_{T H}$ does not Granger Cause $\triangle M P_{U S}$ & & 0.851 & 0.515 \\
\hline
\end{tabular}




\section{References}

Ahn, S., Denis, D.J., Denis, D.K., 2006. Leverage and investment in diversified firms. Journal of Financial Economics 79, 317-337.

Bernanke, B.S., 1993. How important is the credit channel in the transmission of monetary policy?: A comment. Carnegie-Rochester Conference Series on Public Policy 39, 47-52.

Bernanke, B.S., Blinder, A.S., 1988. Credit, money, and aggregate demand. American Economic Review 78, 435-439.

Bernanke, B.S., Blinder, A.S., 1992. The Federal funds rate and the channels of monetary transmission. American Economic Review 82, 901-921.

Bernanke, B.S., Mihov, I., 1997. What does the Bundesbank target? European Economic Review 41, 1025-1053.

Boyle, G.W., Guthrie, G.A., 2003. Investment, uncertainty, and liquidity. Journal of Finance $58,2143-2166$.

Brämer, P., Gischer, H., Richter, T., Weiß, M., 2013. Competition in banks' lending business and its interference with ECB monetary policy. Journal of International Financial Markets, Institutions and Money 25, 144-162.

Brissimis, S.N., Delis, M.D., 2009. Identification of a loan supply function: A cross-country test for the existence of a bank lending channel. Journal of International Financial Markets, Institutions and Money 19, 321-335.

Carlson, M., Shan, H., Warusawitharana, M., 2013. Capital ratios and bank lending: A matched bank approach. Journal of Financial Intermediation 22, 663-687.

Chava, S., Purnanandam, A., 2011. The effect of banking crisis on bank-dependent borrowers. Journal of Financial Economics 99, 116-135. 
Cochrane, J.H., Piazzesi, M., 2002. The Fed and interest rates - A high-frequency identification. American Economic Review 92, 90-95.

Dasgupta, S., Sengupta, K., 2007. Corporate liquidity, investment and financial constraints: Implications from a multi-period model. Journal of Financial Intermediation 16, 151174.

De Haan, L., Sterken, E., 2006. The impact of monetary policy on the financing behaviour of firms in the Euro area and the UK. The European Journal of Finance 12, 401-420.

Disyatat, P., 2011. The bank lending channel revisited. Journal of Money, Credit and Banking 43, 711-734.

Eisner, R., 1975. The Keynesian revolution reconsidered. American Economic Review 65, 189-194.

Fich, E.M., Shivdasani, A., 2006. Are busy boards effective monitors? Journal of Finance 61, $689-724$.

Fourçans, A., Vranceanu, R., 2004. The ECB interest rate rule under the Duisenberg presidency. European Journal of Political Economy 20, 579-595.

Golinelli, R., Rovelli, R., 2005. Monetary policy transmission, interest rate rules and inflation targeting in three transition countries. Journal of Banking \& Finance 29, 183-201.

Hamburger, M.J., 1967. Interest Rates and the Demand for Consumer Durable Goods. American Economic Review 57, 1131-1153.

Hardouvelis, G.A., 1987. Reserves announcements and interest rates: Does monetary policy matter? Journal of Finance 42, 407-422.

Hovakimian, G., 2011. Financial constraints and investment efficiency: Internal capital allocation across the business cycle. Journal of Financial Intermediation 20, 264-283.

Ivashina, V., Scharfstein, D., 2010. Bank lending during the financial crisis of 2008. Journal of Financial Economics 97, 319-338. 
Kashyap, A.K., Stein, J.C., Wilcox, D.W., 1993. Monetary policy and credit conditions: Evidence from the composition of external finance. American Economic Review 83, 78 98.

Kędzior, J., Rozkrut, M., 2014. Short-termism in business: causes, mechanisms and consequences. EY, Warszaw.

Kishan, R.P., Opiela, T.P., 2012. Monetary policy, bank lending, and the risk-pricing channel. Journal of Money, Credit and Banking 44, 573-602.

Kuttner, K.N., 2001. Monetary policy surprises and interest rates: Evidence from the Fed funds futures market. Journal of Monetary Economics 47, 523-544.

Lang, L., Ofek, E., Stulz, R., 1996. Leverage, investment, and firm growth. Journal of Financial Economics 40, 3-29.

Levine, R., 2002. Bank-Based or Market-Based Financial Systems: Which Is Better? Journal of Financial Intermediation 11, 398-428.

Loutskina, E., 2011. The role of securitization in bank liquidity and funding management. Journal of Financial Economics 100, 663-684.

Lyandres, E., 2007. Costly external financing, investment timing, and investment-cash flow sensitivity. Journal of Corporate Finance 13, 959-980.

McLean, R.D., Zhao, M., 2014. The Business Cycle, Investor Sentiment, and Costly External Finance. Journal of Finance 69, 1377-1409.

Milton, F., 1968. The role of monetary policy. American Economic Review 58, 1-17.

Milton, F., 1982. Monetary policy: Theory and practice. Journal of Money, Credit and Banking 14, 98-118.

Mischel, W., Ebbesen, E.B., Raskoff Zeiss, A., 1972. Cognitive and attentional mechanisms in delay of gratification. Journal of Personality and Social Psychology 21, 204-218. 
Moyen, N., 2004. Investment-cash flow sensitivities: Constrained versus unconstrained firms. Journal of Finance 59, 2061-2092.

Moyen, N., Platikanov, S., 2013. Corporate investments and learning. Review of Finance 17, $1437-1488$.

Musso, A., Neri, S., Stracca, L., 2011. Housing, consumption and monetary policy: How different are the US and the euro area? Journal of Banking \& Finance 35, 3019-3041.

Neuenkirch, M., 2013. Monetary policy transmission in vector autoregressions: A new approach using central bank communication. Journal of Banking \& Finance 37, 42784285.

O'Donoghue, T., Rabin, M., 2000. The economics of immediate gratification. Journal of Behavioral Decision Making 13, 233-250.

Pais, A., Stork, P.A., 2013. Bank size and systemic risk. European Financial Management 19, $429-451$.

Rondorf, U., 2012. Are bank loans important for output growth?: A panel analysis of the euro area. Journal of International Financial Markets, Institutions and Money 22, 103-119.

Svensson, L.E.O., 1999. Inflation targeting as a monetary policy rule. Journal of Monetary Economics 43, 607-654.

Tanner, J.E., 1969. Lags in the effects of monetary policy: A statistical investigation. American Economic Review 59, 794-805.

Thorbecke, W., Alami, T., 1992. The Federal funds rate and the arbitrage pricing theory: Evidence that monetary policy matters. Journal of Macroeconomics 14, 731-744.

Tucker, D.P., 1966. Dynamic income adjustment to money-supply changes. American Economic Review 56, 433-449.

Vithessonthi, C., 2014. The effect of financial markets development on bank risk: Evidence from Southeast Asian countries. International Review of Financial Analysis 35, 249-260. 
Vitols, S., 2005. Changes in Germany's Bank-Based Financial System: implications for corporate governance. Corporate Governance: An International Review 13, 386-396.

Yu, Q., 1997. Economic fluctuation, macro control, and monetary policy in the transitional Chinese economy. Journal of Comparative Economics 25, 180-195.

Zhou, L., Wu, W.-p., Luo, X., 2007. Internationalization and the performance of born-global SMEs: the mediating role of social networks. Journal of International Business Studies $38,673-690$.

Zwick, B., 1971. The adjustment of the economy to monetary changes. Journal of Political Economy 79, 77-96. 
Table 1 Descriptive statistics for bank-level variables.

Panel A of this table reports summary statistics for the data on banks used in our sample of 344 bank-year observations for the period 1990-2013. Panel B of this table provides summary statistics for the data on firms used in our sample of 13,283 firm-year observations for the period 1990-2013. Capital expenditure ratio (CAPEX) is measured as the ratio of capital expenditure to prior-period total assets. TA denotes to total assets in millions USD. Leverage ratio $(L E V)$ is computed as the ratio of total debt to total assets. Cash ratio (CASHTA) is computed as the ratio of cash to total assets. Current ratio (CACL) denotes the ratio of current assets to current liabilities. Gross profit margin (GPM) is the ratio of gross profit to net sales. $R O A$ is the ratio of EBIT to total assets. Operating risk (RISK_ROA) is the three-year moving standard deviation of ROA. Fixed asset ratio (FATA) denotes the ratio of non-current assets to total assets. Dividend-to-assets ratio (DIVTA) is calculated as the ratio of cash dividends to total assets. $M B V$ denotes the market to book value ratio. Stock return $\left(S \_R E T U R N\right)$ is computed as the first difference in the natural logarithm of the firm's stock price. Inventory turnover ratio (INVTURN) is the ratio of inventories to cost of goods sold.

\begin{tabular}{|c|c|c|c|c|c|}
\hline & Mean & $\begin{array}{l}\text { Std. } \\
\text { Dev. }\end{array}$ & $\begin{array}{r}\text { 25th } \\
\text { Percentile }\end{array}$ & $\begin{array}{r}\text { 50th Percentile } \\
\text { (Median) }\end{array}$ & $\begin{array}{r}75 \text { th } \\
\text { Percentile }\end{array}$ \\
\hline \multicolumn{6}{|l|}{$\begin{array}{l}\text { Panel A: Bank } \\
\text { variables }\end{array}$} \\
\hline LOANTA (\%) & $\begin{array}{r}70.81 \\
113,287 .\end{array}$ & $\begin{array}{r}22.56 \\
288,058 .\end{array}$ & 80.70 & 61.78 & 85.88 \\
\hline$R E A L \_T A$ & 19 & 92 & $20,300.64$ & $1,682.86$ & $40,217.90$ \\
\hline LLRTA $(\%)$ & 2.30 & 2.73 & 1.27 & 0.28 & 3.32 \\
\hline EQUITYTA (\%) & 6.61 & 4.33 & 5.62 & 3.57 & 8.46 \\
\hline DEPTA $(\%)$ & 59.97 & 22.78 & 67.03 & 22.78 & 78.90 \\
\hline$R O A(\%)$ & 1.36 & 2.07 & 1.49 & 0.73 & 0.73 \\
\hline$M B V$ & 1.47 & 0.96 & 1.35 & 0.92 & 1.98 \\
\hline $\begin{array}{l}\text { INTRATE (\%) } \\
\text { Panel B: Firm } \\
\text { variables }\end{array}$ & 7.73 & 4.82 & 6.22 & 4.64 & 10.08 \\
\hline CAPEX $(\%)$ & 5.84 & 7.12 & 3.75 & 1.69 & 7.14 \\
\hline$R E A L \_T A$ & $2,368.92$ & $8,622.99$ & 166.58 & 49.91 & 655.96 \\
\hline $\operatorname{LEV}(\%)$ & 24.26 & 21.05 & 20.95 & 5.80 & 37.39 \\
\hline CASHTA & 0.13 & 0.14 & 0.09 & 0.03 & 0.19 \\
\hline$C A C L$ & 2.27 & 2.48 & 1.60 & 1.11 & 2.47 \\
\hline $\operatorname{GPM}(\%)$ & 24.02 & 21.56 & 22.15 & 13.18 & 33.87 \\
\hline ROA $(\%)$ & 5.21 & 14.51 & 6.83 & 2.59 & 11.41 \\
\hline$R I S K \_R O A$ & 5.64 & 8.12 & 2.97 & 1.45 & 6.26 \\
\hline FATA & 0.48 & 0.21 & 0.47 & 0.32 & 0.63 \\
\hline DIVTA & 0.02 & 0.12 & 0.01 & 0.00 & 0.03 \\
\hline$M B V$ & 2.03 & 2.97 & 1.33 & 0.78 & 2.30 \\
\hline S_RETURN (\%) & -0.51 & 52.65 & 1.83 & -23.85 & 28.46 \\
\hline INVTURN & 0.33 & 0.75 & 0.19 & 0.07 & 0.32 \\
\hline
\end{tabular}


Table 2 Correlation coefficients for bank-level variables.

This table presents correlation coefficients for key variables in a sample of 344 bank-year observations over the period 1990-2013. Variable definitions are provided in Appendix A. Symbols ***, **, and * denote significance at the $1 \%, 5 \%$ and $10 \%$ levels, respectively.

\begin{tabular}{|c|c|c|c|c|c|c|c|}
\hline & 1 & 2 & 3 & 4 & 5 & 6 & 7 \\
\hline 1. LOANTA & 1.00 & & & & & & \\
\hline 2. LNTA & $-0.37 * * *$ & 1.00 & & & & & \\
\hline 3. LLRTA & $0.29 * * *$ & $0.14 * *$ & 1.00 & & & & \\
\hline 5. DEPTA & $0.65 * * *$ & $-0.18 * * *$ & $0.39 * * *$ & 0.07 & 1.00 & & \\
\hline 6. $R O A$ & $0.09 *$ & $-0.18 * * *$ & $-0.30 * * *$ & $0.45 * * *$ & $-0.19 * * *$ & 1.00 & \\
\hline 7. $M B V$ & -0.01 & -0.07 & -0.04 & $0.14 * *$ & -0.02 & $0.15^{* *}$ & 1.00 \\
\hline
\end{tabular}


Table 3 Correlation coefficients for firm-level variables.

This table presents correlation coefficients for key variables in a sample of 13,283 firm-year observations. Variable definitions are provided in Appendix A. Symbols $* * *, * *$, and $*$ denote significance at the $1 \%, 5 \%$ and $10 \%$ levels, respectively.

\begin{tabular}{|c|c|c|c|c|c|c|c|c|c|c|c|c|}
\hline & 1 & 2 & 3 & 4 & 5 & 6 & 7 & 8 & 9 & 10 & 11 & 12 \\
\hline 1. $C A P E X$ & 1.00 & & & & & & & & & & & \\
\hline 2. LNTA & $0.04 * * *$ & 1.00 & & & & & & & & & & \\
\hline 3. $L E V$ & $0.05 * * *$ & $0.08 * * *$ & 1.00 & & & & & & & & & \\
\hline 4. CASHTA & $-0.11 * * *$ & $-0.09 * * *$ & $-0.41 * * *$ & 1.00 & & & & & & & & \\
\hline 5. $C A C L$ & $-0.09 * * *$ & $-0.18 * * *$ & $-0.35 * * *$ & $0.46^{* * *}$ & 1.00 & & & & & & & \\
\hline 6. $G P M$ & 0.00 & $0.12 * * *$ & $-0.11 * * *$ & $0.15 * * *$ & 0.01 & 1.00 & & & & & & \\
\hline 7. $R O A$ & $0.12 * * *$ & $0.18 * * *$ & $-0.13 * * *$ & $-0.03 * * *$ & $0.04 * * *$ & $0.37 * * *$ & 1.00 & & & & & \\
\hline 8. RISK_ROA & $-0.10 * * *$ & $-0.29 * * *$ & $0.04 * * *$ & $0.17 * * *$ & $0.06 * * *$ & $-0.13 * * *$ & $-0.43 * * *$ & 1.00 & & & & \\
\hline 9. FATA & $0.23 * * *$ & $0.14 * * *$ & $0.29 * * *$ & $-0.43 * * *$ & $-0.29 * * *$ & $0.02 *$ & 0.00 & $-0.12 * * *$ & 1.00 & & & \\
\hline 10. DIVTA & $0.02 * *$ & -0.01 & $-0.07 * * *$ & $0.04 * * *$ & $0.03 * * *$ & $0.07 * * *$ & $0.11 * * *$ & $-0.04 * * *$ & 0.00 & 1.00 & & \\
\hline 11. $M B V$ & $0.07 * * *$ & $0.02 * *$ & $-0.04 * * *$ & $0.11 * * *$ & 0.00 & $0.02 * *$ & $-0.04 * * *$ & $0.07 * * *$ & $-0.05 * * *$ & $0.03 * * *$ & 1.00 & \\
\hline 12. S_RETURN & $0.11 * * *$ & $0.06 * * *$ & $-0.10 * * *$ & 0.01 & $0.02 *$ & $0.11 * * *$ & $0.26 * * *$ & $-0.18 * * *$ & -0.01 & $0.04 * * *$ & $0.09 * * *$ & 1.00 \\
\hline 13. INVTURN & $-0.09 * * *$ & 0.00 & $0.13 * * *$ & $-0.11 * * *$ & $0.12 * * *$ & $0.07 * * *$ & $-0.04 * * *$ & 0.01 & $-0.14 * * *$ & $-0.02 * *$ & $-0.05 * * *$ & $-0.02 * *$ \\
\hline
\end{tabular}


Table 4 OLS and GLM regressions with the lending rate as the dependent variable.

This table reports the results of OLS and GLM regressions with the first difference in the monthly lending rate $(\triangle L E N D I N G)$ as the dependent variable in columns 1-3 and 4-6, respectively. DE, SW and TH denote Germany, Switzerland and Thailand, respectively. $\triangle M P U S$ denotes the first difference in the US monetary policy interest rate (i.e. the effective federal funds rate), whereas $\triangle M P$ denotes the first difference in the policy interest rate for each country. Symbols $* * *, * *$, and * denote significance at the $1 \%, 5 \%$ and $10 \%$ levels, respectively.

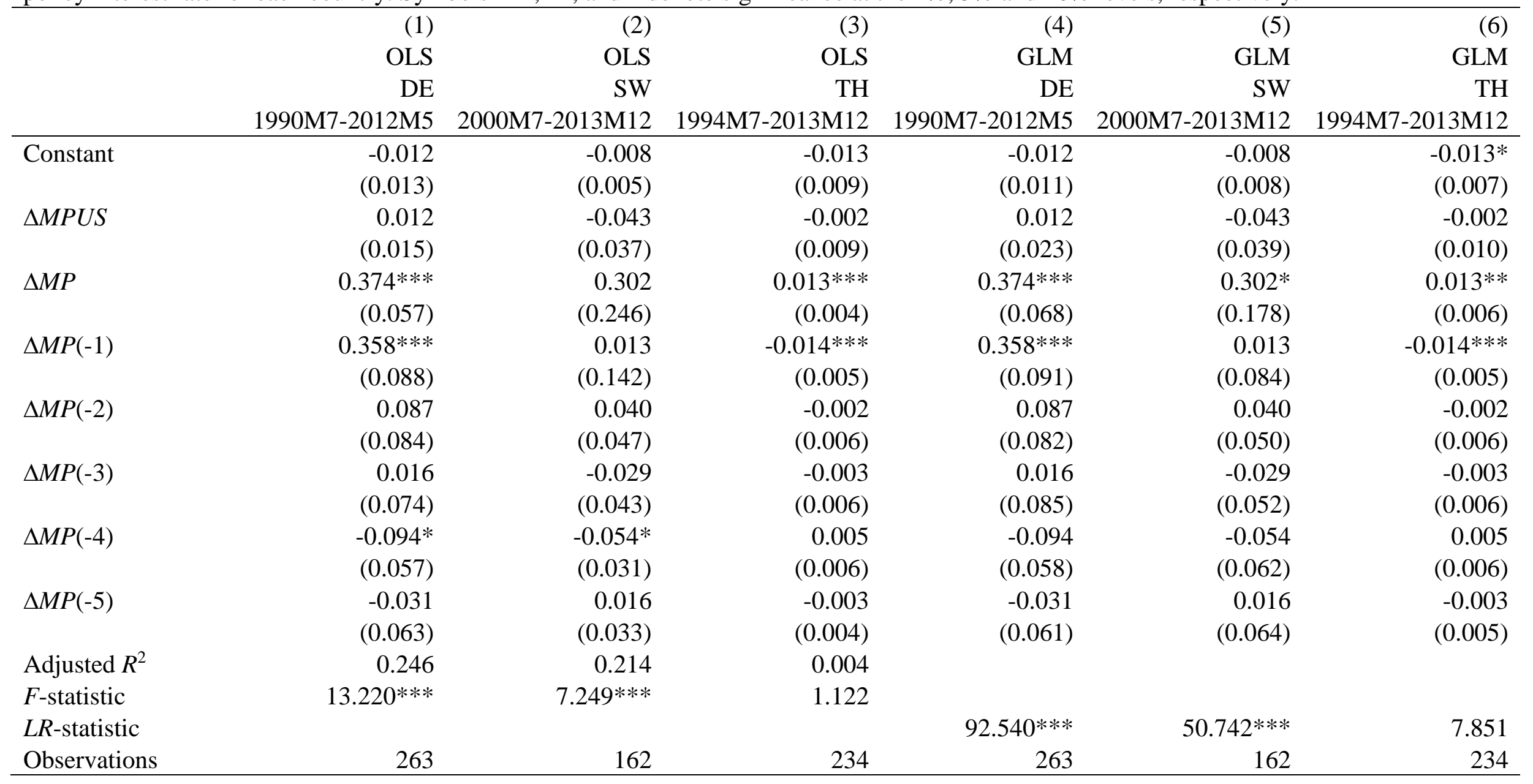


Table 5 Panel OLS regressions of the loan to assets ratio.

This table presents the panel OLS regressions of the loan to assets ratio (LOANTA) on the lending interest rate (INTRATE) for a sample of 25 publicly listed banks in Germany, Switzerland, and Thailand over the period 1990-2013. A global financial crisis (GFC) dummy variable takes a value of 1 for observations between 2007 and 2013 and zero otherwise. A development (DEV) dummy variable takes a value of one for firmyear observations in developed countries and zero otherwise. All right-hand variables are lagged one period. Heteroscedasticity-robust standard errors, which are clustered at the bank level, are reported in parentheses. Symbols ***,**, and $*$ denote significance at the $1 \%, 5 \%$ and $10 \%$ levels, respectively.

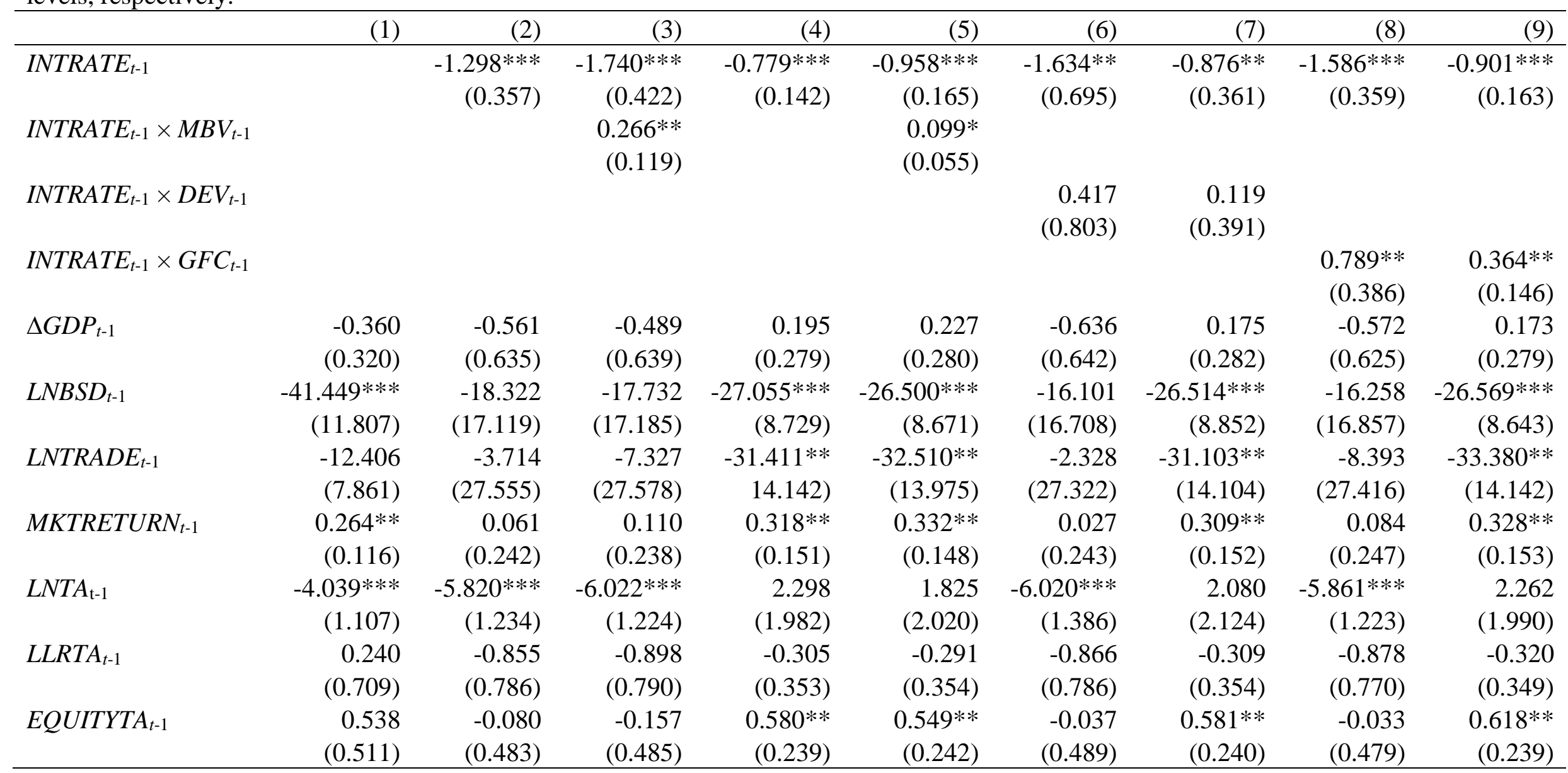




\begin{tabular}{|c|c|c|c|c|c|c|c|c|c|}
\hline \multirow[t]{2}{*}{$D_{E P T A} A_{t-1}$} & $0.534 * * *$ & $0.314 * * *$ & $0.312 * * *$ & -0.070 & -0.068 & $0.310 * * *$ & -0.072 & $0.317 * * *$ & -0.062 \\
\hline & $(0.093)$ & $(0.101)$ & $(0.100)$ & $(0.052)$ & $(0.051)$ & $(0.102)$ & $(0.053)$ & $(0.100)$ & $(0.051)$ \\
\hline$R O A_{t-1}$ & $(0.816)$ & $(0.756)$ & $(0.756)$ & $(0.363)$ & $(0.352)$ & $(0.744)$ & $(0.366)$ & $(0.739)$ & $(0.362)$ \\
\hline$M B V_{\mathrm{t}-1}$ & $(1.335)$ & $(1.380)$ & (1.968) & $(0.618)$ & $(0.861)$ & $(1.366)$ & $(0.617)$ & (1.354) & $(0.618)$ \\
\hline \multirow[t]{2}{*}{ Constant } & $328.766^{* * *}$ & 231.407 & 253.384 & $328.047 * * *$ & $336.677 * * *$ & 219.179 & $326.650 * * *$ & 244.204 & $334.356^{* * *}$ \\
\hline & $(81.552)$ & $(164.722)$ & (166.660) & $(82.069)$ & $(81.663)$ & $(161.612)$ & $(81.726)$ & $(164.287)$ & $(80.718)$ \\
\hline Period fixed effects & No & Yes & Yes & Yes & Yes & Yes & Yes & Yes & Yes \\
\hline Adjusted $\mathrm{R}^{2}$ & 0.574 & 0.695 & 0.701 & 0.943 & 0.943 & 0.695 & 0.943 & 0.700 & 0.944 \\
\hline F-statistic & $40.435 * * *$ & $20.108 * * *$ & $20.101 * * *$ & $85.610 * * *$ & $85.155^{* * *}$ & $19.513 * * *$ & $83.825 * * *$ & $19.970 * * *$ & $85.648 * * *$ \\
\hline Banks included & 25 & 25 & 25 & 25 & 25 & 25 & 25 & 25 & 25 \\
\hline Observations & 294 & 294 & 294 & 294 & 294 & 294 & 294 & 294 & 294 \\
\hline
\end{tabular}


Table 6 Panel quantile regressions of the loan to asset ratio.

This table presents the results of panel quantile regressions of the loan to asset ratio (LOANTA), measured as the total loans to total assets ratio, on the lending interest rate (INTRATE) for a final sample. All explanatory variables are one-period lagged. All estimates are at 25th percentile (Q1), the 50th percentile (median, Q2), and 75th percentile (Q3) using Huber Sandwich standard errors and covariance. Symbols ***, **, and * denote significance at the $1 \%, 5 \%$ and $10 \%$ levels, respectively.

\begin{tabular}{|c|c|c|c|c|c|c|}
\hline & (1) & (2) & (3) & (4) & $(5)$ & (6) \\
\hline & Q1 & $\mathrm{Q} 2$ & Q3 & Q1 & $\mathrm{Q} 2$ & Q3 \\
\hline $\operatorname{INTRATE}_{t-1}$ & $(0.449)$ & $(0.216)$ & $(0.804)$ & $(0.686)$ & $(0.264)$ & $(0.761)$ \\
\hline$I N T R A T E_{t-1} \times M B V_{\mathrm{t}-1}$ & & & & $(0.193)$ & $(0.095)$ & $(0.083)$ \\
\hline \multirow[t]{2}{*}{$\Delta G D P_{t-1}$} & -0.086 & -0.428 & -0.099 & 0.044 & -0.418 & -0.097 \\
\hline & $(0.653)$ & $(0.457)$ & $(0.232)$ & $(0.554)$ & $(0.460)$ & $(0.227)$ \\
\hline \multirow[t]{2}{*}{$L N T R A D E_{t-1}$} & -1.313 & $-15.676^{* * *}$ & -12.724 & -1.672 & $-14.960 * * *$ & -11.980 \\
\hline & (7.609) & $(5.461)$ & $(9.188)$ & (7.170) & $(5.635)$ & $(8.860)$ \\
\hline \multirow[t]{2}{*}{ MKTRETURN $_{t-1}$} & 0.003 & $0.439 *$ & 0.240 & 0.025 & $0.436^{*}$ & 0.248 \\
\hline & $(0.316)$ & $(0.224)$ & $(0.172)$ & $(0.276)$ & $(0.231)$ & $(0.171)$ \\
\hline$L N T A_{\mathrm{t}-1}$ & -1.700 & $-3.987 * * *$ & $-3.458 * * *$ & -1.986 & $-4.044 * * *$ & $-3.531 * * *$ \\
\hline$E Q U I T Y T A_{t-1}$ & $(0.539)$ & $(0.509)$ & $(0.539)$ & $(0.531)$ & $(0.528)$ & $(0.517)$ \\
\hline \multirow{2}{*}{$D E P T A_{t-1}$} & $0.725 * * *$ & $0.375 * * *$ & $0.296 * * *$ & $0.708 * * *$ & $0.377 * * *$ & $0.290 * * *$ \\
\hline & $(0.213)$ & $(0.093)$ & $(0.085)$ & $(0.217)$ & $(0.095)$ & $(0.082)$ \\
\hline \multirow[t]{2}{*}{$R O A_{t-1}$} & 1.652 & 0.024 & 0.990 & 1.918 & 0.065 & 0.809 \\
\hline & (1.209) & $(0.855)$ & $(0.921)$ & (1.399) & $(0.860)$ & $(0.887)$ \\
\hline$M B V_{\mathrm{t}-1}$ & 0.654 & -0.310 & 0.038 & -1.609 & -1.155 & -1.203 \\
\hline
\end{tabular}




\begin{tabular}{|c|c|c|c|c|c|c|}
\hline \multirow{3}{*}{ Constant } & $(1.115)$ & $(0.888)$ & $(1.269)$ & $(2.458)$ & $(1.321)$ & $(1.363)$ \\
\hline & 193.951 & $352.343^{* * *}$ & $209.511 * * *$ & 220.829 & $352.463 * * *$ & $210.423 * * *$ \\
\hline & (123.138) & $(76.663)$ & (71.064) & (133.623) & $(78.297)$ & $(70.655)$ \\
\hline Pseudo $\mathrm{R}^{2}$ & 0.517 & 0.339 & 0.191 & 0.521 & 0.339 & 0.194 \\
\hline Quasi-LR statistic & $408.568 * * *$ & $209.396 * * *$ & $98.871 * * *$ & $410.571 * * *$ & $206.567 * * *$ & $100.357 * * *$ \\
\hline Banks included & 25 & 25 & 25 & 25 & 25 & 25 \\
\hline Observations & 294 & 294 & 294 & 294 & 294 & 294 \\
\hline
\end{tabular}


Table 7 Panel OLS regressions of the capital expenditure ratio.

This table presents the panel OLS regressions of the capital expenditure ratio (CAPEX) on the lending rate (LENDING) and the loan-to-asset ratio (ALOANTA) for a final sample of publicly listed firms in Germany, Switzerland, and Thailand over the period 1990-2013. All right-hand variables are lagged one period. Heteroscedasticity-robust standard errors, which are clustered at the firm level, are reported in parentheses. Country-fixed effects and year-fixed effects are included in all regressions. Symbols ***,**, and * denote significance at the $1 \%, 5 \%$ and $10 \%$ levels, respectively.

\begin{tabular}{|c|c|c|c|c|c|c|}
\hline & $(1)$ & $(2)$ & $(3)$ & (4) & $(5)$ & $(6)$ \\
\hline$A L O A N T A_{t-1}$ & & & $0.066 * * *$ & $0.059 * *$ & $0.059 * *$ & $0.059 * *$ \\
\hline \multirow[t]{2}{*}{$L E N D I N G_{t-1} \times M B V_{\mathrm{t}-1}$} & & & & & 0.000 & \\
\hline & & & & & $(0.000)$ & \\
\hline$A L O A N T A_{t-1} \times M B V_{\mathrm{t}-1}$ & & & & & & 0.000 \\
\hline$\Delta G D P_{\mathrm{t}-1}$ & $(0.035)$ & $(0.036)$ & $(0.035)$ & $(0.036)$ & $(0.036)$ & $(0.036)$ \\
\hline \multirow[t]{2}{*}{$T R A D E_{t-1}$} & -0.009 & $-0.031 *$ & -0.015 & $-0.030 *$ & $-0.030 *$ & $-0.030^{*}$ \\
\hline & $(0.016)$ & $(0.017)$ & $(0.016)$ & $(0.017)$ & $(0.017)$ & $(0.017)$ \\
\hline \multirow[t]{2}{*}{ MKTRETURN $N_{t-1}$} & $0.016 * * *$ & $0.014 * * *$ & $0.012 * * *$ & $0.011 * * *$ & $0.011 * * *$ & $0.011 * * *$ \\
\hline & $(0.004)$ & $(0.004)$ & $(0.004)$ & $(0.004)$ & $(0.004)$ & $(0.004)$ \\
\hline \multirow[t]{2}{*}{ CASHTA $_{t-1}$} & $2.097 * * *$ & $2.161^{* * *}$ & $2.298 * * *$ & $2.322 * * *$ & $2.322 * * *$ & $2.322 * * *$ \\
\hline & $(0.762)$ & $(0.762)$ & $(0.761)$ & $(0.761)$ & $(0.761)$ & $(0.761)$ \\
\hline \multirow[t]{2}{*}{$C A C L_{t-1}$} & -0.024 & -0.026 & -0.028 & -0.029 & -0.029 & -0.029 \\
\hline & $(0.038)$ & $(0.038)$ & $(0.038)$ & $(0.038)$ & $(0.038)$ & $(0.038)$ \\
\hline$G P M_{t-1}$ & $-0.013 * * *$ & $-0.013 * * *$ & $-0.013 * * *$ & $-0.012 * * *$ & $-0.012 * * *$ & $-0.012 * * *$ \\
\hline
\end{tabular}




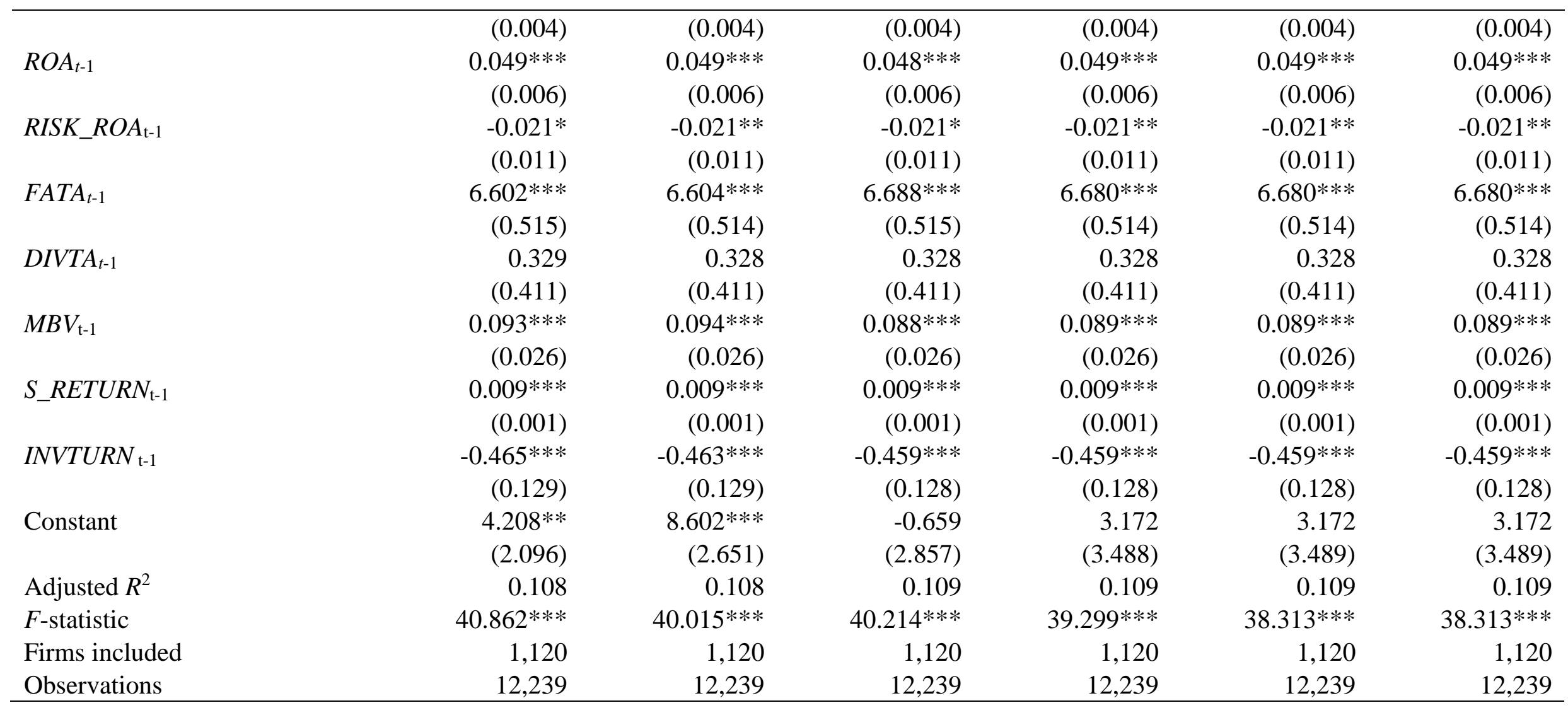


Table 8 Panel OLS regressions of the capital expenditure ratio: Subsample analysis.

This table presents the panel OLS regressions of the capital expenditure ratio (CAPEX) on the lending rate (LENDING) and the loan-to-asset ratio (ALOANTA) for a final sample of publicly listed firms in Germany, Switzerland, and Thailand over the period 1990-2013. Columns 1-3 report the results for the full sample; columns 4 and 5 report the results for the financially unconstrained firms and the financially constrained firms, respectively; columns 6 and 7 report the results for the no sales growth firms and positive sales growth firms, respectively; columns 8 and 9 present the results for the poor performing firms and the good performing firms, respectively. A financial constraint (FINC) dummy variable takes a value of one for a firm that does not pay dividends at time $t$-1, and zero otherwise. A sales growth $(S G R O W)$ dummy variable takes a value of one for a firm that has a positive growth rate of net sales at time $t-1$, and zero otherwise. A good performance $(P E R F)$ dummy variable takes a value of one for a firm that has a positive value of $R O A$ at time $t-1$, and zero otherwise. All right-hand variables are lagged one period. Heteroscedasticity-robust standard errors, which are clustered at the firm level, are reported in parentheses. Country-fixed effects and year-fixed effects are included in all regressions. Symbols $* * *, * *$, and * denote significance at the $1 \%, 5 \%$ and $10 \%$ levels, respectively.

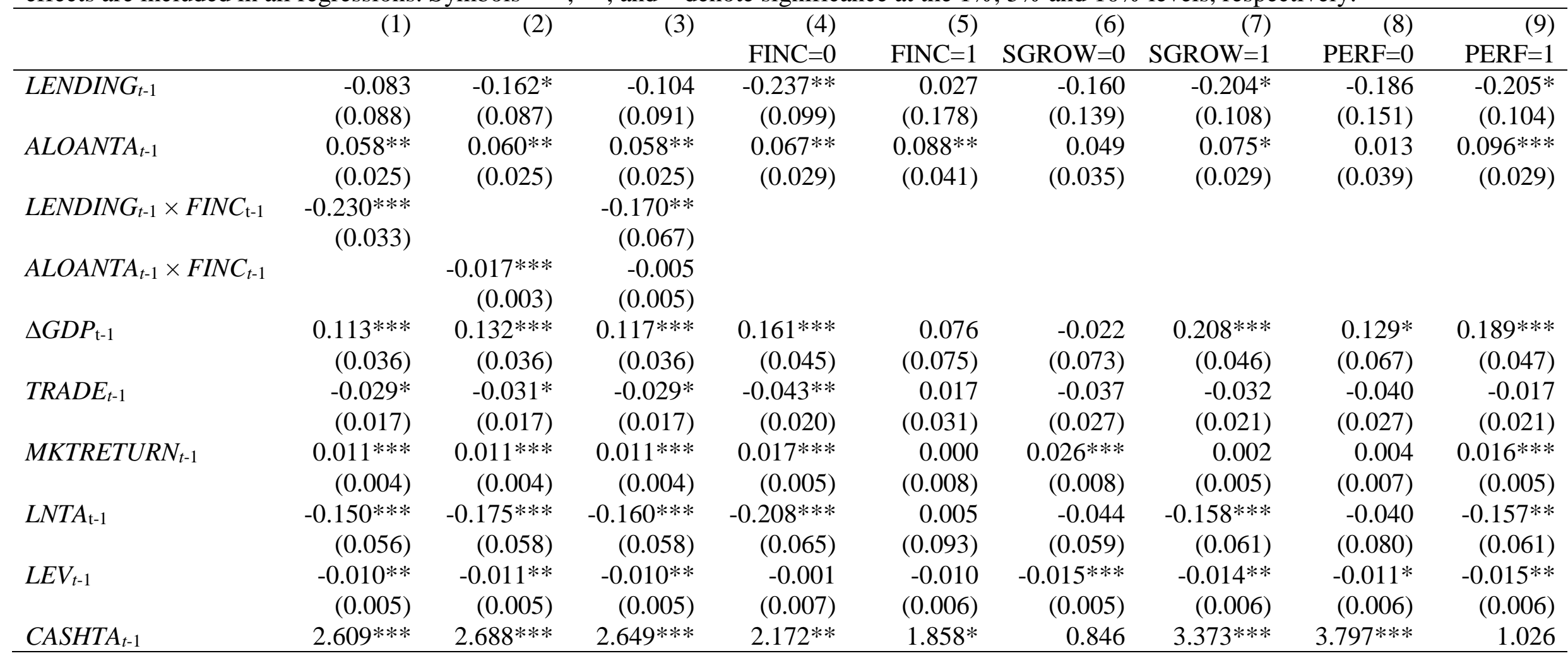




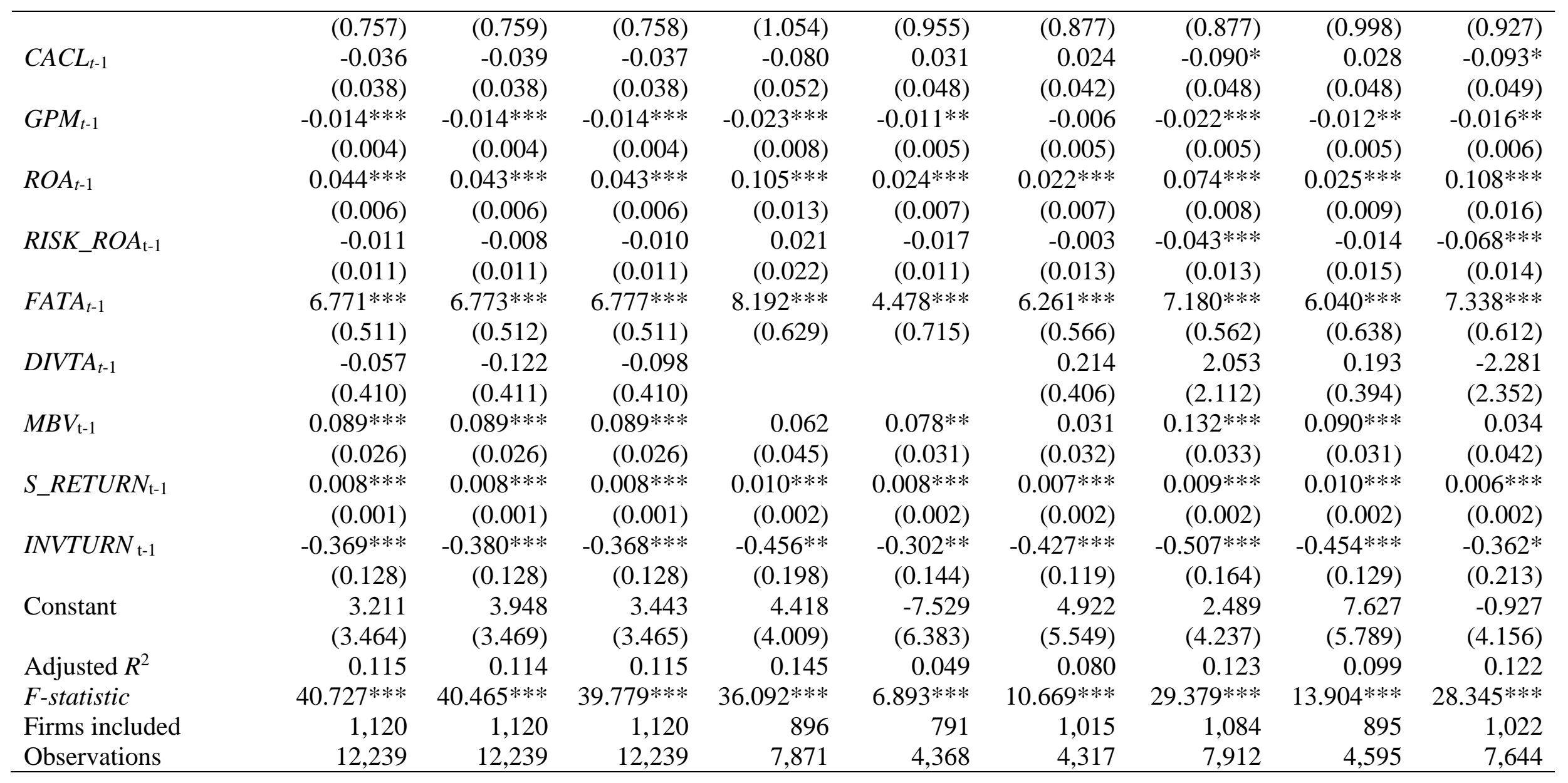

